\title{
Stable isotopes, carbon-14 and hydrochemical composition from a basaltic aquifer in São Paulo State, Brazil
}

\author{
Didier Gastmans ${ }^{1}\left[\right.$ I $_{0}$ Amauri Antônio Menegário ${ }^{1} \cdot$ Ian Hutcheon $^{2}$
}

Received: 3 February 2016/Accepted: 6 February 2017/Published online: 13 February 2017

(C) Springer-Verlag Berlin Heidelberg 2017

\begin{abstract}
The Cretaceous Serra Geral Aquifer (SGA) is contained within one of the largest continental flood basalts in the world, reaching a thickness up to $1700 \mathrm{~m}$ in the center of the Paraná Basin. The SGA is one of the most important groundwater reservoirs in northeastern São Paulo State (Brazil), responsible for water supply to cities and agriculture. In order to evaluate the geochemical and isotopic evolution of SGA, as well as to determine the mean residence time, a groundwater sampling campaign was carried out over the SGA in São Paulo State (Brazil) from January to April 2013. Two main hydrochemical facies were recognized: $\mathrm{Ca}-\mathrm{Mg}-\mathrm{HCO}_{3}$ related to water-rock interaction reactions in basaltic outcrop, such as mineral dissolution due to atmospheric $\mathrm{CO}_{2}$ uptake, and alkaline $\mathrm{Na}-\mathrm{HCO}_{3}$ groundwater, evolved from mixing with groundwater from the underlying Guarani Aquifer System. Stable isotope $\left(\delta^{18} \mathrm{O}\right.$ and $\left.\delta^{2} \mathrm{H}\right)$ ratios range from -8.87 to $-5.32 \%$ VSMOW and -61.31 to $-31.64 \%$ VSMOW, respectively, closely following the GMWL. Spatial and temporal variations in isotope ratios are associated with the South Atlantic convergence zone activities and the type of
\end{abstract}

Didier Gastmans

gastmans@rc.unesp.br

Amauri Antônio Menegário

amenega@rc.unesp.br

Ian Hutcheon

ian@earth.geo.ucalgary.ca

1 Environmental Studies Center, São Paulo State University (UNESP), Av. 24A, 1515 - Bela Vista, Rio Claro, SP CEP 13506-900, Brazil

2 Applied Geochemistry Group, Department of Geoscience, University of Calgary, 2500 University Drive NW, Calgary, $\mathrm{AB}$, Canada rain responsible for recharge. Values for $\delta^{13} \mathrm{C}$ vary from -21.53 to $-7.11 \%$ VPDB, while ${ }^{14} \mathrm{C}$ activities vary from $1.2 \mathrm{pcm}$ to more than $100 \mathrm{pcm}$, presenting a trend to enrichment and decrease in ${ }^{14} \mathrm{C}$ activities westward, concordant with the regional groundwater flow direction. Most recent groundwaters have $\delta^{13} \mathrm{C}$ ratio contents mostly consistent with $\mathrm{C} 3$ plants.

Keywords Serra Geral Aquifer - Hydrochemistry · Stable isotopes · Groundwater age · Brazil

\section{Introduction}

Basaltic rock aquifers represent an important groundwater resource, constituting excellent aquifer units, hosting water supply in several parts of the world, mainly due to the excellent quality of the stored water, generally characterized by low salinity. Basaltic lava flows present geologic structures that provide discontinuities responsible for groundwater storage and flow in these units (Deutsch et al. 1982; Domenico and Schwartz 1998; Dafny et al. 2006). Due to heterogeneities associated with groundwater flow in basaltic aquifers, mainly related to discontinuities in the lava flows, different approaches have to be used as auxiliary tools to deduce groundwater flow within basaltic aquifers (Léonardi et al. 1996; Rosenthal et al. 1998; Locsey and Cox 2003; Dafny et al. 2006; Bretzler et al. 2011; Alemayehu et al. 2011; Gastmans et al. 2016).

Evaluation of groundwater residence times based on ${ }^{14} \mathrm{C}$ measurements, combined with stable isotope data and the hydrochemical evolution, is being increasingly used, especially in studies focused on understanding the flow condition and origin of groundwater in fractured and heterogeneous aquifers. Hydrochemical studies enable the 
definition of chemical reactions, due to processes of waterrock interaction that are responsible for the chemical characteristics, while stable isotope ratios provide information about the origin of the groundwater and past climatic conditions during recharge. ${ }^{14} \mathrm{C}$ activities determine the residence time of the water in the aquifer. These methods can also be used to identify quality changes in groundwater associated with anthropogenic sources of contamination (Plummer et al. 1990; Rosenthal et al. 1998; Glynn and Plummer 2005; Betheke and Johnson 2008; Coetsiers and Walraevens 2009; Blaser et al. 2010; Bretzler et al. 2011; Abid et al. 2014; Scheiber et al. 2015; among others).

In the southeastern portion of South America, basalts from the Serra Geral Formation cover an area of over $1,200,000 \mathrm{~km}^{2}$, representing one of the largest observed continental basaltic floods. Lava flows, mostly basalts and andesites (Milani et al. 1994), are up to $1700 \mathrm{~m}$ thick toward the center of the Paraná Sedimentary Basin. This stratigraphic unit represents an important aquifer, responsible for public water supply, irrigation and industrial uses, largely in the states of Paraná, Santa Catarina, Rio Grande do Sul and Mato Grosso do Sul, Brazil, where most part of hydrochemical studies of groundwater in the SGA have been carried out. These studies allowed groundwater chemical characterization and the establishment of the hydraulic relationship with the underlying unit, the Guarani Aquifer (Bittencourt et al. 2003; Lastoria et al. 2006; Boff et al. 2006; among others).

Due to the importance of Mesozoic sedimentary aquifers for water supply in the western portion of São Paulo State (Bauru and Guarani Aquifer), the hydrodynamics and hydrochemistry have been studied since the 1970s (Gallo and Sinelli 1980; Sracek and Hirata 2002; Gastmans et al. 2010a, b; among others), and several conceptual models for groundwater flow and hydrochemical evolution have been formulated. However, geochemical evolution and determination of residence times of the SGA in São Paulo State, based on chemistry, stable isotopes and radiogenic ${ }^{14} \mathrm{C}$, have not been yet studied extensively.

The main purpose of this paper is to address questions regarding the regional functioning of the Serra Geral Aquifer in São Paulo State. This paper: (1) evaluates the geochemical characteristics of groundwater from SGA, (2) establishes recharge conditions based on the stable isotope composition of groundwater, (3) provides constrains on the mean residence time of groundwater using radiocarbon age dates.

\section{Geological and hydrogeological settings}

Basalts of the Serra Geral Formation are present in the Paraná Magmatic Province (PMP), which constitutes one of the largest volcanic igneous manifestations of basic rocks in a continental area, inserted in Paraná Sedimentary Basin (Fig. 1). This magmatic province includes lava flows and intrusive basic rocks (sills and dykes) representing an important contribution to generation of continental crust during the Mesozoic related to the Atlantic breakout (Milani et al. 1994). Some important structures from this intracratonic basin are associated with the breakout, such as the Ponta Grossa Arch located in Paraná State, whose axis strikes N45 W. Parallel to the arch important distension faults are recognized, up to the border between São Paulo and Paraná states, represented by the Paranapanema River.

The radiometric ages indicate that volcanic activity began between 133 and $132 \mathrm{Ma}$, starting in the south and moving toward the north in a relatively short time interval of approximately 3 Ma (Renne et al. 1992, 1996; Ernesto et al. 1999). This vast volume of basaltic lavas reaches thicknesses up to $1700 \mathrm{~m}$ toward the center of the Paraná Sedimentary Basin and was deposited over the eolian sandstones of the Botucatu Formation. Breaks in magmatic events are marked by the occurrence of beds of sandstones interfingered with the basalt ("intertrap sandstones") that originated by the movement of desert dunes over the basaltic substrate (Zalán et al. 1986; Scherer 2000).

Three major lithotypes associated with the Serra Geral Formation are recognized based on petrographic and geochemical differences. The greatest part of the magmatic volume (up to 97\%) is represented by basalts and andesites, while in the southern region of Brazil rhyodacites and rhyolites [Palmas (ATP) and rhyodacites and quartz latites Chapecó (ATC)] are recognized, representing, respectively, 2.5 and $0.5 \%$ of magmatic volume (Bellieni et al. 1986; Nardy et al. 2002). In São Paulo State there are mainly basalts of mafic to intermediate composition, consisting of plagioclase (mainly labradorite), pyroxene (augite and pigeonite) and olivine, mainly as pseudomorphs, with modal percentages ranging from 25 to 50,20 to 40 and $4 \%$, respectively. Vesicular zones of variable thickness are recognized at the boundary between basaltic lava flow events. Secondary minerals forming amygdales fill these vesicles, including quartz, calcite, zeolites, fluorite and commonly greenish clays, probably of the celadonite group (Machado et al. 2007). The weathering of basaltic rocks produces very deep soils in the southern portion of Brazil. Three main weathering pathways for plagioclase phenocrystals from basaltic rocks have been recognized: plagioclase to gibbsite; plagioclase to gels (amorphous silica) and gibbsite; and plagioclase to gels (amorphous silica), gibbsite and kaolinite. Pyroxenes weather to smectite and goethite or to goethite and gibbsite (Clemente and Azevedo 2007).

The generic hydrogeological model for groundwater flow in the basalts of the Serra Geral Formation encompasses permeable and impermeable zones for each lava 

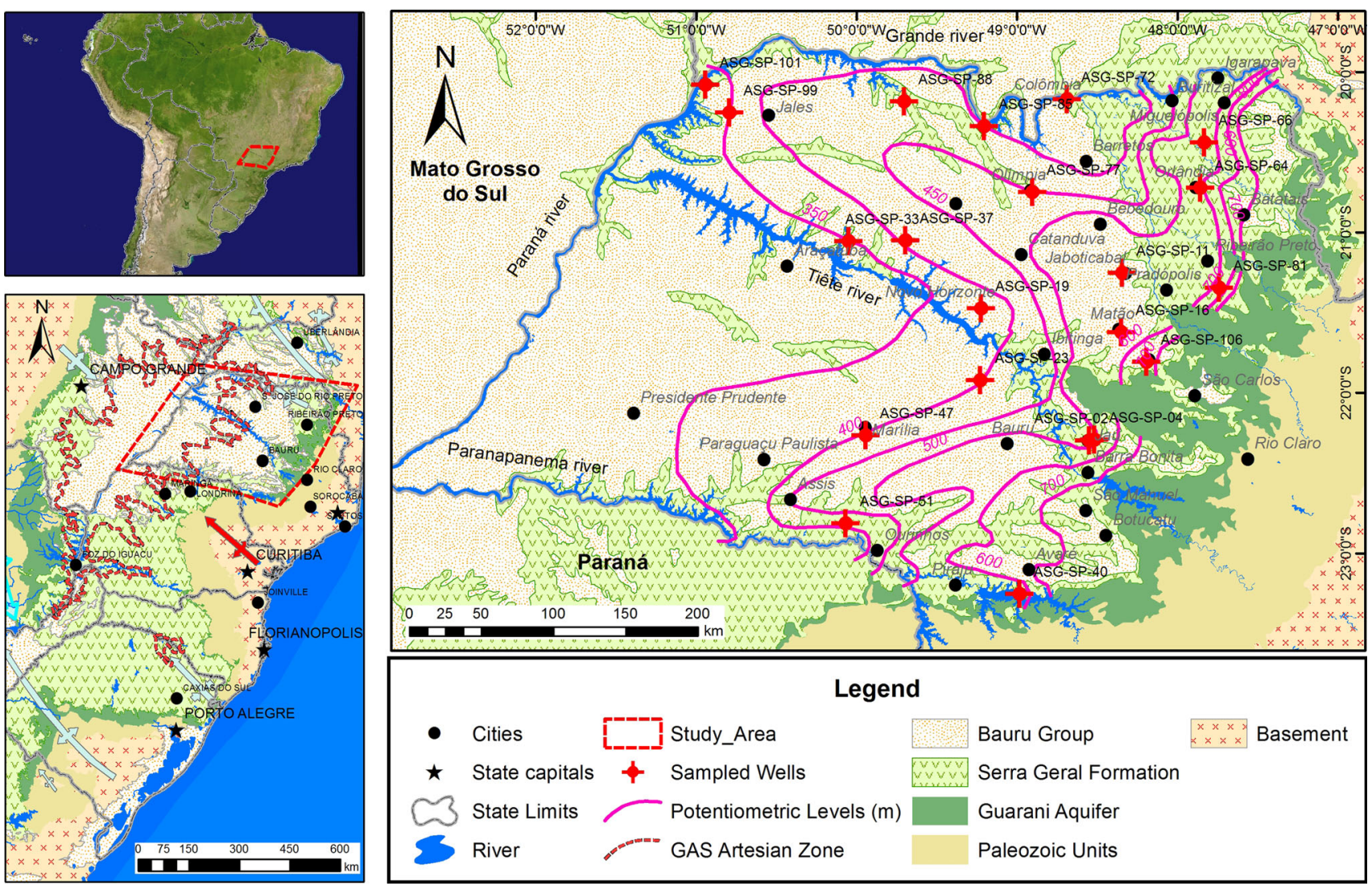

Fig. 1 Left map location map of the Serra Geral Aquifer, showing in detail the study area and the artesian zone of Guarani Aquifer System located along the Paraná River and in red the strike of the Ponta Grossa Arch (regional geological base map modified from OAS 2009). Right map location map of sampled wells showing the

flow event. At the top and bottom of each sequence a highly permeable zone is observed, associated with basalt weathering, and groundwater flow is associated with the occurrence of a vesicular basaltic layer that has extensive horizontal fractures. The central portion of each sequence represents an aquitard, where minor vertical movement of water is associated with vertical discontinuities (joints and fractures) (Rebouças and Fraga 1988). In the northeastern portion of the aquifer in São Paulo State, recharge toward the underlying unit, the Guarani Aquifer, was proposed (Wahnfried 2010; Fernandes et al. 2010). Based on chemical and isotopic tracers, groundwater flow was inferred to be predominantly along horizontal discontinuities in the basaltic rocks, and a lack of vertical flow through the geological lineaments identified by aerial surveys that limits recharge of the Guarani Aquifer by water from the Serra Geral basalts.

Groundwater from the SGA has low electrical conductivities, due to low total dissolved solids, and a wide range of $\mathrm{pH}$ values, from acid to alkaline. The chemical composition shows the groundwater to be mainly $\mathrm{Ca}-\mathrm{HCO}_{3}$ simplified groundwater potentiometric map for SGA in the study area, based on water level information from wells' reports archived in DAEE (Dep. Águas e Energia Elétrica do Estado de São Paulo) (Local geological base map modified from DAEE/UNESP 1980)

and $\mathrm{Ca}-\mathrm{Mg}-\mathrm{HCO}_{3}$ type (DAEE 1974, 1976; Campos 1993). In the northwestern region of São Paulo State hydrochemical anomalies have been recognized, characterized by TDS values up to $200 \mathrm{mg} \mathrm{L}^{-1}$, and associated with fractures or faults filled by hydrothermal mineralization. These may be due to contamination by more saline waters originating from underlying aquifers (DAEE 1976).

In the northeastern portion of São Paulo State, groundwater flow in Serra Geral aquifer is driven by the topography, and the main rivers crossing the area represent local discharge of the aquifer. The existence of higher pressure head in wells drilled in the Guarani Aquifer System indicates the possibility of groundwater flow into the overlying basalts, and potentially, mixing of groundwater. SGA groundwater composition is directly related to the influence of water-rock interactions, mainly due to the dissolution of plagioclase and pyroxene, in the presence of atmospheric $\mathrm{CO}_{2}$, leading to secondary formation of kaolinite and releasing calcium, sodium, magnesium, silica and bicarbonate to solution. Modifications in chemical composition of groundwater due to upward flow from Guarani Aquifer 
along Rio Grande, state border between São Paulo and Minas Gerais states, were confirmed using NETPATH modeling (Gastmans et al. 2016).

\section{Methods}

Twenty-one groundwater samples were collected directly from water supply wells between January 2013 and April 2013. The location of sampled wells, drilled in basalts of the SGA, is presented in Fig. 1, and information about depth of the wells and elevation is presented in Table 1. The $\mathrm{pH}$, electrical conductivity and temperature of each water sample were measured in situ. Each sample was filtered $(0.45 \mu \mathrm{m})$, and part was acidified using $\mathrm{HNO}_{3}$ to $\mathrm{pH}<2$ for cation analysis and part preserved refrigerated $\left(\sim 4{ }^{\circ} \mathrm{C}\right.$ ) for anion analysis. Samples collected for the determination of water isotopic ratios $\left(\delta^{18} \mathrm{O}\right.$ and $\left.\delta^{2} \mathrm{H}\right)$ were stored in $200-\mathrm{mL}$ polyethylene bottles, avoiding the presence of headspace inside to prevent evaporation. Samples collected for $\delta^{13} \mathrm{C}$ and for ${ }^{14} \mathrm{C}$ activity were stored in 500-mL amber glass bottles, also avoiding the presence of headspace to prevent $\mathrm{CO}_{2}$ isotopic exchange. Samples for cation and anion determination were delivered within a week to the laboratory, and samples for isotopic determination were delivered at the end of the sampling campaign.

Stable isotope ratios $\left(\delta^{18} \mathrm{O}, \delta^{2} \mathrm{H}\right.$ and $\left.\delta^{13} \mathrm{C}\right)$ and ${ }^{14} \mathrm{C}$ activities (pmc) were analyzed in the Environmental Isotope Laboratory at the Department of Earth and Environmental Sciences at the University of Waterloo, Canada. $\delta^{18} \mathrm{O}$ and $\delta^{2} \mathrm{H}$ ratios were determined using laser absorption spectroscopy, and the results reported as \%o relative to Vienna Standard Mean Ocean Water (VSMOW). ${ }^{14} \mathrm{C}$ activities and $\delta^{13} \mathrm{C}$ ratios were determined using accelerator mass spectrometry (AMS), with a precision of $0.4 \mathrm{pmc}$ and $0.15 \%$, respectively.

The cation and anion concentrations in groundwater samples were determined in the Hydrogeology and Hydrogeochemistry Laboratory of the Department of Applied Geology IGCE/UNESP Rio Claro. Alkalinity was determined by titration, anions $\left(\mathrm{F}, \mathrm{Cl}, \mathrm{NO}_{3}\right.$ and $\left.\mathrm{SO}_{4}\right)$ were measured by ion chromatography, and cations (Na, K, Ca, $\mathrm{Mg}$ and $\mathrm{Si}$ ) were measured by ICP-AES. The quality of water analyses was checked by charge balance $\left(\Delta_{\mathrm{meq}}=100 \bullet\left(\sum_{\mathrm{meq}}^{+}-\sum_{\mathrm{meq}}^{-}\right) /\left(\sum_{\mathrm{meq}}^{+}+\sum_{\mathrm{meq}}^{-}\right)<10 \%\right)$. All samples were less than $10 \%$, with samples ASG-SP-47 and ASG-SP-101 showing a difference of about $12 \%$, acceptable for the purpose of this work. Results of field measured data, chemical and isotopic data are presented in Tables 1 and 2, respectively.

The geochemical computer program PHREEQC (Parkhurst and Appelo 1999) was used to calculate the $\mathrm{P}_{\mathrm{CO}_{2}}$ in the groundwater, as well as saturation index for some mineral species (Table 2) at the temperature measured in the field. If the temperature was not measured, calculations were performed at $25^{\circ} \mathrm{C}$, which is considered to be the average temperature in the aquifer. To calculate individual groundwater residence times based on ${ }^{14} \mathrm{C}$ activity, the modeling code NETPATH XL (Plummer et al. 1994; Parkhurst and Charlton 2008) was used.

\section{Results and discussion}

Groundwater flow in the study area for the SGA is driven by the topography, with flow from elevated areas located to the east, where basalts outcrop between 700 and 600 masl, and westward toward the main rivers that cross São Paulo State SW-NE (Grande, Tietê and Paranapanema rivers), about 300-350 masl. Two groundwater divides were recognized, where sediments of the Bauru Group cover the SGA, accompanying the watershed division between these main rivers (Fig. 1). This behavior indicates that SGA in the study area represents an unconfined aquifer, at least in the outcrop zone, and the main rivers represent discharge zones for the aquifer. Along the major rivers in the western portion of São Paulo State, an important regional hydrogeological feature is observed, the artesian zone of the GAS, which indicates the possibility of upward groundwater flow from the underlying Guarani toward basaltic discontinuities (Fig. 1).

\section{Groundwater chemical and isotopic composition}

The amount of dissolved solids of SGA groundwater varies from 1.35 to $8.28 \mathrm{mmol} \mathrm{L}^{-1}$ (arithmetic mean of $4.61 \mathrm{mmol} \mathrm{L}^{-1}$ ), and electric conductivity (EC) varies from 48.3 to $413 \mu \mathrm{S} \mathrm{cm}^{-1}$ (arithmetic mean of 215.1 $\mu \mathrm{S} \mathrm{cm}{ }^{-1}$ ), reflecting the low content of solutes. Values of $\mathrm{pH}$ vary from 6.4 to 10.2 (arithmetic mean of 8.3 ), indicating the existence of acid and alkaline water in the aquifer. Table 3 summarizes the correlation between measured physicochemical parameters. EC and $\mathrm{pH}$ have a strong correlation $(r=0.86)$, mainly related to the control exerted over $\mathrm{pH}$ by $\mathrm{CO}_{3}$ and total alkalinity $(r=0.90$ and 0.63 , respectively), which represents the most abundant anion in SGA groundwater (Fig. 2) and explains the correlation between total alkalinity, EC and TDS $(r=0.90$ and 0.92 , respectively).

Chloride and $\mathrm{NO}_{3}$ concentrations show a wide range of values (from 0.002 to $0.255 \mu \mathrm{mol} \mathrm{L}{ }^{-1} \mathrm{Cl}$ and from 0.001 to $0.463 \mu \mathrm{mol} \mathrm{L} \mathrm{L}^{-1} \mathrm{NO}_{3}$ ) and have a good correlation $(r=0.82)$, which could indicate an anthropogenic origin for these compounds due to leakage of sanitation systems as observed in some cities of São Paulo State (Bertolo et al. 2006). This origin is corroborated by the low correlation 
Table 1 Hydrochemical data set (concentrations in $\left.\mathrm{mmol} \mathrm{L} \mathrm{L}^{-1}\right)$

\begin{tabular}{|c|c|c|c|c|c|c|c|c|c|c|c|c|}
\hline \multicolumn{2}{|c|}{ Sample } & \multicolumn{3}{|c|}{ Locality } & \multicolumn{2}{|l|}{ Date } & $\begin{array}{l}\text { Alt. } \\
\text { m }\end{array}$ & \multicolumn{2}{|c|}{ Well depth } & $\begin{array}{l}\mathrm{EC} \\
\text { us } \mathrm{cm}^{-1}\end{array}$ & $\mathrm{pH}$ & $\begin{array}{l}\text { Temp } \\
\left({ }^{\circ} \mathrm{C}\right)\end{array}$ \\
\hline \multicolumn{2}{|c|}{ ASG-SP-02 } & \multicolumn{3}{|l|}{ Jaú } & \multicolumn{2}{|c|}{$14 / 01 / 13$} & 497 & 150 & \multicolumn{2}{|c|}{237.0} & 7.2 & 24.3 \\
\hline \multicolumn{2}{|c|}{ ASG-SP-04 } & \multicolumn{3}{|l|}{ Jaú } & \multicolumn{2}{|c|}{$14 / 01 / 13$} & 550 & 150 & \multicolumn{2}{|c|}{102.2} & 7.2 & 24.2 \\
\hline \multicolumn{2}{|c|}{ ASG-SP-11 } & \multicolumn{3}{|c|}{ Jaboticabal } & \multicolumn{2}{|c|}{$16 / 01 / 13$} & 596 & 150 & & 57.1 & 7.8 & 24.0 \\
\hline ASG-S & -16 & Matãc & & & $18 / 01 /$ & & 531 & 180 & & 70.0 & 9.9 & 26.7 \\
\hline ASG-S & -19 & Novo & Horizon & & $18 / 01 /$ & & 422 & 300 & & 15.0 & 9.0 & 27.0 \\
\hline ASG-S & -23 & Regin & ópolis & & $19 / 01 /$ & & 452 & 250 & & 54.0 & 9.9 & 27.5 \\
\hline ASG-S & -33 & Zacar & & & $21 / 01 /$ & & 390 & 115 & & 74.0 & 10.0 & 25.8 \\
\hline ASG-S & -37 & José I & onifáci & & $22 / 01 /$ & & 405 & 125 & & 26.0 & 10.0 & 27.9 \\
\hline ASG-S & -40 & Avaré & & & $05 / 03 /$ & & 616 & 110 & & 48.3 & 6.4 & 23.3 \\
\hline ASG-S & -47 & Maríl & & & 06/03/ & & 468 & 300 & & 13.0 & 10.2 & 26.5 \\
\hline ASG-S & -51 & Ibirar & ma & & 07/03/ & & 481 & 120 & & 04.0 & 7.8 & 24.4 \\
\hline ASG-S & -64 & Orlân & & & 19/03/ & & 693 & 125 & & 09.2 & 7.2 & 24.2 \\
\hline ASG-S & ?-66 & Guará & & & $20 / 03 /$ & & 644 & 145 & & 96.4 & 7.2 & 28.0 \\
\hline ASG-S & -72 & Colôn & bia & & $21 / 03 /$ & & 485 & 145 & & 94.9 & 7.3 & 26.8 \\
\hline ASG-S & -77 & Olím & & & $22 / 03 /$ & & 476 & 161 & & 47.0 & 8.0 & 25.2 \\
\hline ASG-S & -81 & Cravi & hos & & $22 / 03 /$ & & 690 & 115 & & 15.7 & 7.6 & 23.9 \\
\hline ASG-S & -85 & Icém & & & $01 / 04$ & & 431 & 151 & & 01.0 & 9.7 & 27.3 \\
\hline ASG-S & -88 & Ponte & Gestal & & $02 / 04 /$ & & 462 & 100 & & 49.5 & 7.8 & 26.6 \\
\hline ASG-S & ?-99 & Sant. & Ponte $\mathrm{P}$ & nsa & 03/04/ & & 414 & 220 & & 14.0 & 8.2 & 25.5 \\
\hline ASG-S & -101 & Sta. C & lara do & Oeste & 03/04/ & & 355 & 250 & & 96.4 & 7.6 & 28.5 \\
\hline ASG-S & -106 & Arara & quara & & $05 / 04$ & & 661 & 135 & & 92.0 & 7.9 & $\mathrm{~nm}$ \\
\hline $\begin{array}{l}\mathrm{HCO}_{3} \\
(\mathrm{mmol}\end{array}$ & $\begin{array}{l}\mathrm{CO}_{3} \\
\left.\mathrm{~L}^{-1}\right)\end{array}$ & $\begin{array}{l}\text { Total } \\
\text { Alk. }\end{array}$ & $\mathrm{Cl}$ & $\mathrm{NO}_{3}$ & $\mathrm{SO}_{4}$ & $\mathrm{~F}$ & $\mathrm{Na}$ & K & $\mathrm{Ca}$ & $\mathrm{Mg}$ & $\mathrm{Si}$ & $\begin{array}{l}\text { Mass } \\
\text { balance } \\
\%\end{array}$ \\
\hline 1.868 & nd & 1.868 & 0.255 & 0.229 & 0.026 & 0.007 & 0.423 & $3 \quad 0.031$ & 0.644 & 0.444 & 1.065 & 4.37 \\
\hline 0.829 & nd & 0.829 & 0.051 & 0.121 & 0.001 & 0.004 & 0.144 & 0.038 & 0.274 & 0.189 & 0.780 & 4.89 \\
\hline 1.596 & nd & 1.596 & 0.002 & 0.001 & 0.000 & 0.004 & 0.207 & 0.182 & 0.462 & 0.190 & 0.997 & 2.70 \\
\hline 1.573 & 1.015 & 2.588 & 0.014 & 0.001 & 0.031 & 0.024 & 4.006 & $5 \quad 0.009$ & 0.021 & 0.005 & 0.605 & 4.69 \\
\hline 1.655 & 0.126 & 1.781 & 0.076 & 0.040 & 0.098 & 0.012 & 2.375 & 0.003 & 0.039 & 0.003 & 0.566 & 4.89 \\
\hline 0.919 & 0.810 & 1.729 & 0.032 & 0.001 & 0.012 & 0.007 & 2.597 & 0.016 & 0.064 & 0.037 & 0.680 & 3.90 \\
\hline 1.408 & 1.155 & 2.563 & 0.009 & 0.001 & 0.022 & 0.011 & 4.480 & 0.008 & 0.013 & 0.000 & 0.602 & 8.84 \\
\hline 1.096 & 1.030 & 2.126 & 0.014 & 0.001 & 0.047 & 0.010 & 3.558 & $3 \quad 0.005$ & 0.013 & 0.001 & 0.602 & 4.63 \\
\hline 0.542 & nd & 0.542 & 0.008 & 0.004 & 0.001 & 0.003 & 0.072 & 0.086 & 0.164 & 0.058 & 0.409 & 3.67 \\
\hline 0.819 & 1.533 & 2.353 & 0.026 & 0.001 & 0.052 & 0.022 & 5.176 & $5 \quad 0.001$ & 0.012 & 0.001 & 0.634 & 12.60 \\
\hline 1.000 & nd & 1.000 & 0.019 & 0.038 & 0.000 & 0.002 & 0.144 & 0.025 & 0.319 & 0.188 & 0.691 & 5.52 \\
\hline 1.029 & nd & 1.029 & 0.018 & 0.097 & 0.001 & 0.004 & 0.274 & t 0.043 & 0.339 & 0.139 & 0.634 & 5.08 \\
\hline 0.724 & nd & 0.724 & 0.060 & 0.181 & 0.001 & 0.003 & 0.592 & 0.017 & 0.145 & 0.062 & 0.360 & 2.60 \\
\hline 1.254 & nd & 1.254 & 0.252 & 0.463 & 0.002 & 0.004 & 0.439 & 0.031 & 0.569 & 0.289 & 1.054 & 5.02 \\
\hline 2.032 & nd & 2.032 & 0.235 & 0.369 & 0.008 & 0.003 & 0.887 & 0.056 & 0.753 & 0.176 & 0.584 & 2.69 \\
\hline 1.060 & nd & 1.060 & 0.048 & 0.120 & 0.001 & 0.004 & 0.151 & 0.048 & 0.372 & 0.205 & 0.726 & 4.62 \\
\hline 0.808 & 0.675 & 1.483 & 0.162 & 0.010 & 0.362 & 0.107 & 3.223 & $3 \quad 0.018$ & 0.053 & 0.016 & 0.694 & 3.35 \\
\hline 1.639 & nd & 1.639 & 0.013 & 0.032 & 0.000 & 0.001 & 0.866 & 0.035 & 0.334 & 0.101 & 0.488 & 2.50 \\
\hline 3.343 & nd & 3.343 & 0.109 & 0.146 & 0.003 & 0.020 & 0.792 & 0.036 & 0.776 & 0.992 & 0.883 & 9.27 \\
\hline 1.950 & nd & 1.950 & 0.085 & 0.091 & 0.001 & 0.008 & 0.280 & 0.095 & 0.604 & 0.551 & 1.150 & 11.35 \\
\hline 1.375 & nd & 1.375 & 0.072 & 0.166 & 0.022 & 0.021 & 0.375 & $5 \quad 0.070$ & 0.536 & 0.221 & 0.741 & 7.71 \\
\hline
\end{tabular}

$n m$ not measured, $n d$ not detected 
Table 2 Isotopic data set and thermodynamic calculations

\begin{tabular}{|c|c|c|c|c|c|c|c|c|c|c|}
\hline Sample & Locality & $\begin{array}{l}\delta^{18} \mathrm{O} \\
\% \text { VSN }\end{array}$ & $\begin{array}{r}\delta^{2} \mathrm{H} \\
\text { IOW }\end{array}$ & $\begin{array}{l}\delta^{13} \mathrm{C} \\
\% \text { VPDB }\end{array}$ & $\begin{array}{l}{ }^{14} \mathrm{C} \\
\mathrm{pmc}\end{array}$ & SI_Calcite & $\log \mathrm{P}_{\mathrm{CO}_{2}}$ & SI_SiO ${ }_{2}(\mathrm{a})$ & SI_Chalcedony & SI_Quartz \\
\hline ASG-SP-02 & Jaú & -6.31 & -41.3 & -15.34 & 105.73 & -0.73 & -2.15 & -0.26 & 0.59 & 1.02 \\
\hline ASG-SP-04 & Jaú & -6.55 & -40.17 & -15.71 & 108.85 & -1.41 & -2.50 & -0.39 & 0.45 & 0.88 \\
\hline ASG-SP-11 & Jaboticabal & -7.31 & -45.13 & -20.61 & 79.32 & -0.33 & -2.82 & -0.29 & 0.56 & 0.99 \\
\hline ASG-SP-16 & Matão & -8.79 & -59.55 & -7.98 & 3.67 & 0.10 & -5.08 & -0.89 & -0.05 & 0.37 \\
\hline ASG-SP-19 & Novo Horizonte & -7.34 & -48.14 & -12.72 & 22.39 & -0.22 & -4.02 & -0.62 & 0.21 & 0.64 \\
\hline ASG-SP-23 & Reginópolis & -8.28 & -52.97 & -11.68 & 17.63 & 0.43 & -5.31 & -0.85 & -0.02 & 0.41 \\
\hline ASG-SP-33 & Zacarias & -7.56 & -50.58 & -8.01 & 13.46 & -0.10 & -5.25 & -0.93 & -0.1 & 0.33 \\
\hline ASG-SP-37 & José Bonifácio & -7.61 & -50.72 & -8.64 & 12.48 & -0.15 & -5.35 & -0.97 & -0.14 & 0.28 \\
\hline ASG-SP-40 & Avaré & -6.48 & -39.01 & -19.87 & 80.37 & -2.60 & -1.88 & -0.66 & 0.18 & 0.62 \\
\hline ASG-SP-47 & Marília & -8.28 & -55.83 & -7.11 & 1.22 & -0.14 & -5.66 & -1.06 & -0.23 & 0.20 \\
\hline ASG-SP-51 & Ibirarema & -5.43 & -34.49 & -21.53 & 97.35 & -0.67 & -3.02 & -0.45 & 0.39 & 0.82 \\
\hline ASG-SP-64 & Orlândia & -7.03 & -46.21 & -16.26 & 97.58 & -1.22 & -2.40 & -0.48 & 0.36 & 0.79 \\
\hline ASG-SP-66 & Guará & -6.13 & -41.34 & -16.53 & 83.73 & -1.68 & -2.53 & -0.76 & 0.07 & 0.49 \\
\hline ASG-SP-72 & Colômbia & -6.56 & -41.44 & -17.73 & 102.52 & -0.81 & -2.41 & -0.28 & 0.55 & 0.98 \\
\hline ASG-SP-77 & Olímpia & -7.33 & -45.14 & -16.05 & 72.24 & 0.17 & -2.92 & -0.53 & 0.31 & 0.74 \\
\hline ASG-SP-81 & Cravinhos & -6.99 & -43.11 & -17.85 & 97.03 & -0.78 & -2.80 & -0.42 & 0.42 & 0.86 \\
\hline ASG-SP-85 & Icém & -7.43 & -50.51 & -15.12 & 38.94 & 0.19 & -5.08 & -0.73 & 0.1 & 0.52 \\
\hline ASG-SP-88 & Pontes Gestal & -6.70 & -43.94 & -17.59 & 71.34 & -0.42 & -2.79 & -0.62 & 0.22 & 0.64 \\
\hline ASG-SP-99 & Sant. Ponte Pensa & -6.41 & -42.67 & -18.41 & 67.53 & 0.55 & -2.92 & -0.36 & 0.48 & 0.91 \\
\hline ASG-SP-101 & Sta. Clara do Oeste & -6.77 & -43.75 & -12.63 & 36.24 & -0.29 & -2.51 & -0.26 & 0.57 & 0.99 \\
\hline ASG-SP-106 & Araraquara & -7.28 & -44.84 & -14.16 & 97.4 & -0.22 & -2.98 & -0.42 & 0.42 & 0.85 \\
\hline
\end{tabular}

observed between $\mathrm{Cl}$ and $\mathrm{Na}(r=-0.22)$, excluding the possibility of groundwater recharge by precipitation affected by salt dissolution or evaporative enrichment of rainwater. Therefore, chloride cannot be used as a conservative tracer to interpret residence times of groundwater using ${ }^{14} \mathrm{C}$. Concentrations of $\mathrm{Cl}+\mathrm{NO}_{3}$ are greater than the concentration of $\mathrm{SO}_{4}$ (usually $<0.01 \mu \mathrm{mol} \mathrm{L}{ }^{-1}$ ), and only one sample (ASG-SP-85) has high $\mathrm{SO}_{4}$ concentration. Dissolved cations are dominated by calcium and magnesium, which do not have a good correlation with TDS or total alkalinity, but have a good correlation with each other $(r=0.80)$ and with $\mathrm{HCO}_{3}(r=0.65$ for $\mathrm{Ca}$ and $r=0.78$ for $\mathrm{Mg}$ ). Sodium concentration increase is observed, strongly correlated with EC, TDS, $\mathrm{pH}$ and $\mathrm{CO}_{3}$ (respectively, $r=0.86, r=0.83,0.94$ and $r=0.96$ ).

The concentration of cations and anions in SGA groundwater allows the identification of two main hydrochemical facies: $\mathrm{Ca}-\mathrm{Mg}-\mathrm{HCO}_{3}$ and $\mathrm{Na}-\mathrm{HCO}_{3}$ waters, as presented in the Piper diagram (Fig. 2). $\mathrm{Ca}-\mathrm{Mg}-\mathrm{HCO}_{3}$ groundwater has $\mathrm{Ca}$ as the most abundant cation, followed by $\mathrm{Mg}$, in variable relative concentrations, reaching ratios between $\mathrm{Ca}$ and $\mathrm{Mg}$ values close to 1 . Relative concentrations of $\mathrm{Na}$ and $\mathrm{K}$ in these samples are very low, but an increase in the contribution of $\mathrm{Cl}+\mathrm{NO}_{3}$ is observed.
These samples show $\mathrm{pH}$ varying from acid to neutral values. $\mathrm{Na}-\mathrm{HCO}_{3}$ waters are characterized by the occurrence of $\mathrm{Na}$ as the most abundant cation, with relative concentrations of $\mathrm{Ca}, \mathrm{Mg}$ and $\mathrm{K}$ that are much smaller. An increase in $\mathrm{SO}_{4}$ is observed in two samples, and $\mathrm{pH}$ values indicate alkaline waters.

The relationship between the isotopic ratios of oxygen and hydrogen of samples from SGA groundwater is presented in Fig. 3, with the Global Meteoric Water Line (GMWL) and the Brazilian Tropical Meteoric Water Line (BTMWL) $\quad\left[\delta^{2} \mathrm{H}=7.7 \quad \delta^{18} \mathrm{O}+10.1 \quad\left(r^{2}=0.95\right)\right]$. This latter line is based on isotopic data from stations located in the tropical region of Brazil (Cuiabá, Brasilia, Campo Grande, Rio de Janeiro and Porto Alegre) available in the GNIP database (IAEA/WMO 2006, available at http://iso his.iaea.org). SGA groundwater exhibits isotopic ratios from -59.6 to $-34.5 \%$ VSMOW for $\delta^{2} \mathrm{H}$, and -8.8 to $-5.4 \%$ VSMOW for $\delta^{18} \mathrm{O}$. Comparing the groundwater data to rainwater from GNIP stations shows that most groundwater has an isotopic signature similar to rainwater, and plots along the two meteoric lines, indicating a meteoric origin for the recharge of this groundwater (Fig. 3).

Spatial distribution of $\delta^{18} \mathrm{O}$ (Fig. 4a) shows more enriched values for isotopic ratios in the southern zone of the 
Table 3 Correlation matrix

\begin{tabular}{|c|c|c|c|c|c|c|c|c|c|}
\hline & $\mathrm{EC}$ & $\mathrm{pH}$ & $\delta^{13} \mathrm{C}$ & ${ }^{14} \mathrm{C}$ & $\mathrm{HCO}_{3}$ & $\mathrm{CO}_{3}$ & Tot.Alk & $\mathrm{Cl}$ & $\mathrm{NO}_{3}$ \\
\hline $\mathrm{EC}$ & 1.00 & - & - & - & - & - & - & - & - \\
\hline $\mathrm{pH}$ & 0.86 & 1.00 & - & - & - & - & - & - & - \\
\hline$\delta^{13} \mathrm{C}$ & 0.78 & 0.79 & 1.00 & - & - & - & - & - & - \\
\hline${ }^{14} \mathrm{C}$ & -0.77 & -0.89 & -0.81 & 1.00 & - & - & - & - & - \\
\hline $\mathrm{HCO}_{3}$ & 0.31 & -0.02 & -0.07 & -0.02 & 1.00 & - & - & - & - \\
\hline $\mathrm{CO}_{3}$ & 0.81 & 0.90 & 0.84 & -0.84 & -0.24 & 1.00 & - & - & - \\
\hline Tot.Alk & 0.86 & 0.63 & 0.54 & -0.62 & 0.72 & 0.50 & 1.00 & - & - \\
\hline $\mathrm{Cl}$ & 0.10 & -0.22 & -0.17 & 0.31 & 0.33 & -0.30 & 0.08 & 1.00 & - \\
\hline $\mathrm{NO}_{3}$ & -0.18 & -0.48 & -0.30 & 0.55 & 0.26 & -0.49 & -0.12 & 0.82 & 1.00 \\
\hline $\mathrm{SO}_{4}$ & 0.33 & 0.44 & 0.17 & -0.32 & -0.19 & 0.31 & 0.05 & 0.22 & -0.23 \\
\hline $\mathrm{F}$ & 0.41 & 0.44 & 0.18 & -0.30 & -0.09 & 0.33 & 0.16 & 0.20 & -0.23 \\
\hline $\mathrm{Na}$ & 0.86 & 0.94 & 0.85 & -0.89 & -0.13 & 0.96 & 0.57 & -0.22 & -0.46 \\
\hline K & -0.44 & -0.50 & -0.53 & 0.38 & 0.15 & -0.50 & -0.22 & -0.08 & 0.02 \\
\hline $\mathrm{Ca}$ & -0.25 & -0.60 & -0.54 & 0.62 & 0.65 & -0.69 & 0.09 & 0.58 & 0.69 \\
\hline $\mathrm{Mg}$ & -0.03 & -0.38 & -0.36 & 0.35 & 0.78 & -0.47 & 0.36 & 0.38 & 0.38 \\
\hline $\mathrm{Si}$ & 0.07 & -0.19 & -0.14 & 0.24 & 0.43 & -0.25 & 0.21 & 0.46 & 0.34 \\
\hline \multirow[t]{2}{*}{ TDS } & 0.99 & 0.83 & 0.74 & -0.77 & 0.39 & 0.77 & 0.90 & 0.12 & -0.17 \\
\hline & $\mathrm{SO}_{4}$ & $\mathrm{~F}$ & \multicolumn{2}{|c|}{$\mathrm{Na}$} & K & $\mathrm{Ca}$ & $\mathrm{Mg}$ & $\mathrm{Si}$ & TDS \\
\hline EC & - & \multicolumn{2}{|l|}{-} & - & - & - & - & - & - \\
\hline $\mathrm{pH}$ & - & \multicolumn{2}{|l|}{-} & - & - & - & - & - & - \\
\hline$\delta^{13} \mathrm{C}$ & - & \multicolumn{2}{|l|}{-} & - & - & - & - & - & - \\
\hline${ }^{14} \mathrm{C}$ & - & \multicolumn{2}{|l|}{-} & - & - & - & - & - & - \\
\hline $\mathrm{HCO}_{3}$ & - & \multicolumn{2}{|l|}{-} & - & - & - & - & - & - \\
\hline $\mathrm{CO}_{3}$ & - & \multicolumn{2}{|l|}{-} & - & - & - & - & - & - \\
\hline Tot.Alk & - & \multicolumn{2}{|l|}{-} & - & - & - & - & - & - \\
\hline $\mathrm{Cl}$ & - & \multicolumn{2}{|l|}{-} & - & - & - & - & - & - \\
\hline $\mathrm{NO}_{3}$ & - & \multicolumn{2}{|l|}{-} & - & - & - & - & - & - \\
\hline $\mathrm{SO}_{4}$ & 1.00 & \multicolumn{2}{|l|}{-} & - & - & - & - & - & - \\
\hline F & 0.95 & \multicolumn{2}{|c|}{1.00} & - & - & - & - & - & - \\
\hline $\mathrm{Na}$ & 0.42 & \multicolumn{2}{|c|}{0.41} & 1.00 & - & - & - & - & - \\
\hline K & -0.26 & -0.21 & & -0.57 & 1.00 & - & - & - & - \\
\hline $\mathrm{Ca}$ & -0.36 & -0.26 & & -0.70 & 0.48 & 1.00 & - & - & - \\
\hline $\mathrm{Mg}$ & -0.26 & -0.11 & & -0.47 & 0.26 & 0.80 & 1.00 & - & - \\
\hline $\mathrm{Si}$ & -0.08 & -0.01 & & -0.30 & 0.41 & 0.61 & 0.64 & 1.00 & - \\
\hline TDS & 0.32 & 0.39 & & 0.83 & -0.41 & -0.20 & 0.05 & 0.13 & 1.00 \\
\hline
\end{tabular}

Correlation values in bold showing significance level $\rho<0.001$

SGA (sample ASG-SP-51), while in the northern and central basaltic outcrop zones the isotopic ratios are slightly depleted.

The $\delta^{13} \mathrm{C}$ ratios vary from -21.53 to $-7.11 \%$ VPDB, with a trend to enrichment westward, concordant with the main groundwater flow direction. In the basalt outcrop, $\delta^{13} \mathrm{C}$ presents variable values. In the northern portion $\delta^{13} \mathrm{C}$ ratios are about $-16.5 \%$ VPDB, while in the central zone these values are about $-15.5 \%$ VPDB, and in the southern portion more depleted values are observed, about $-21.5 \%$ VPDB (Fig. 4b).

Considering the existence of equilibrium between the carbonate system in groundwater and the atmospheric $\mathrm{CO}_{2}$ in outcrop zones, as previously discussed, it is possible to calculate the values of $\delta^{13} \mathrm{C}$ of $\mathrm{CO}_{2}$ using the following expression:

$\delta^{13} \mathrm{C}_{g-e q}=\delta_{T}-\left(\frac{a \varepsilon_{a-g}+b \varepsilon_{b-g}+c \varepsilon_{c-g}}{m \mathrm{HCO}_{3}}\right)$ 


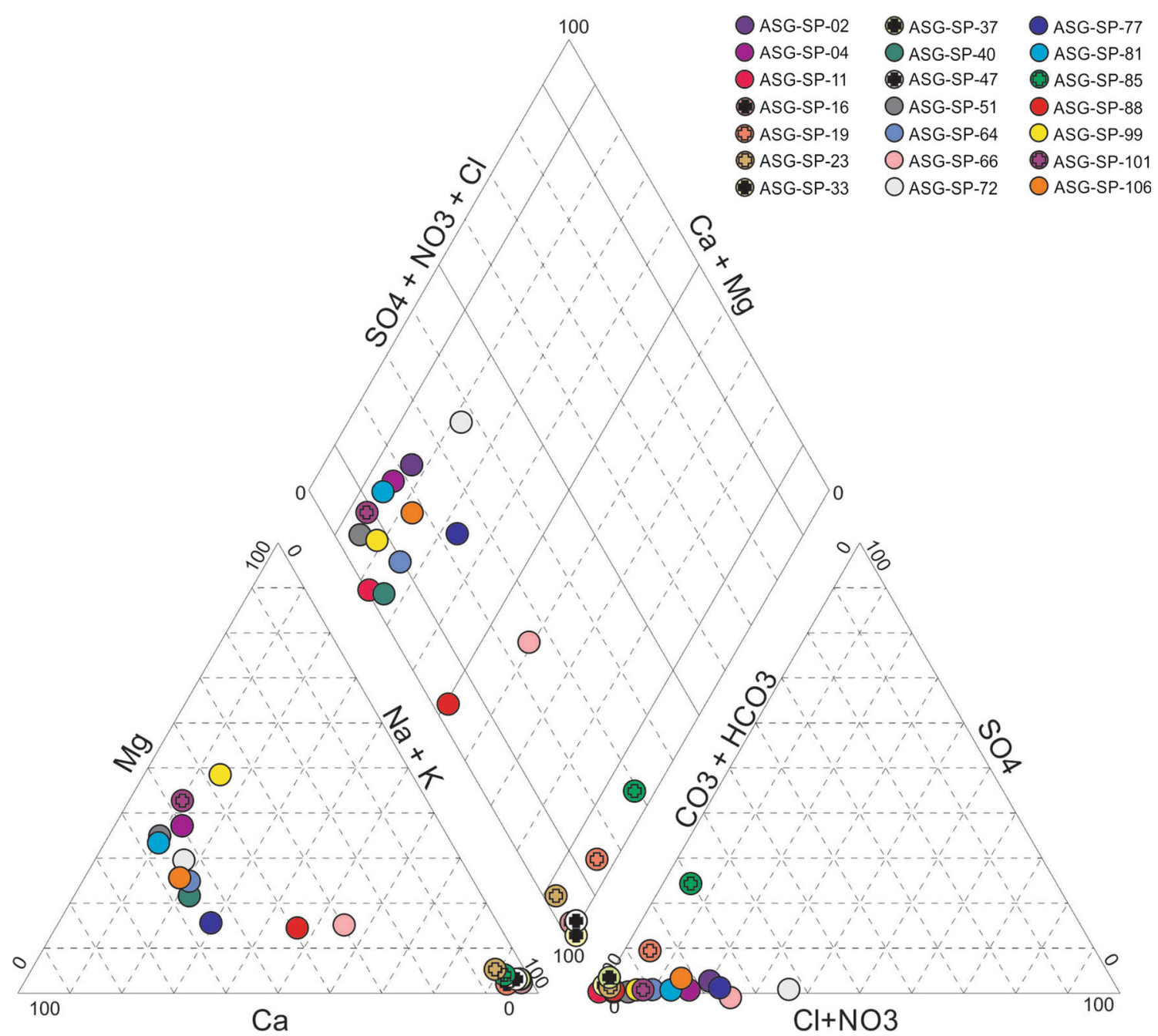

Fig. 2 Piper diagram. Samples from Groups 02 and 03 are marked with cross and black cross, respectively

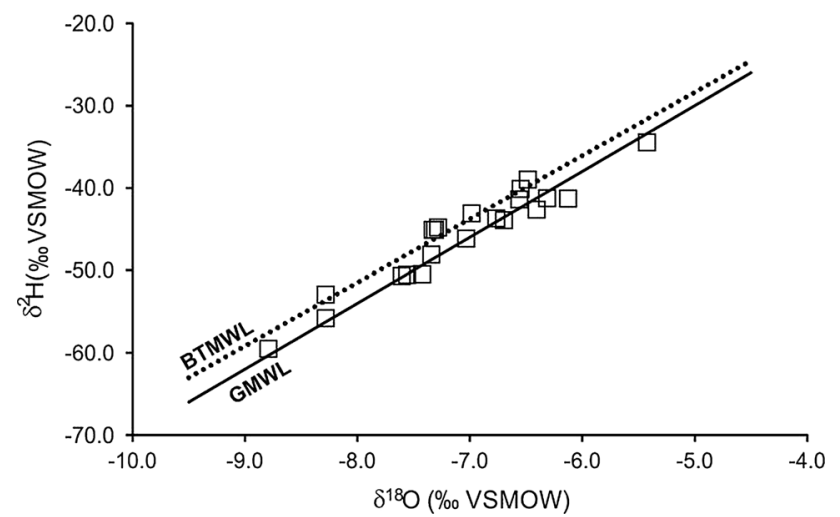

Fig. $3 \delta^{18} \mathrm{O}$ versus $\delta 2 \mathrm{H}$ cross-plot for SAGS groundwater from the study area. Brazilian Tropical Meteoric Water Line (BTMWL dashed line) and Global Meteoric Water Line (GMWL solid line) are shown

where $\delta_{\mathrm{T}}$ is the measured $\delta^{13} \mathrm{C}$ in groundwater; $\mathrm{a}, \mathrm{b}$ and $\mathrm{c}$ stand for molarities of $\mathrm{H}_{2} \mathrm{CO}_{3}, \mathrm{HCO}_{3}$, and $\mathrm{CO}_{3}{ }^{2-}$, respectively; $\varepsilon_{\mathrm{a}-\mathrm{g}}, \varepsilon_{\mathrm{b}-\mathrm{g}}, \varepsilon_{\mathrm{c}-\mathrm{g}}$ are the fractionation factors between the carbon species at equilibrium; and $\mathrm{mHCO}_{3}$ is the total dissolved inorganic carbon content $\left(\mathrm{mol} \mathrm{L}^{-1}\right)$.

Based on the range of values for calculated $\delta^{13} \mathrm{C}^{-1} \mathrm{CO}_{2}$ in soils, $\mathrm{HCO}_{3}$ concentrations and $\delta^{13} \mathrm{C}$ of groundwater, three groups of samples can be distinguished. Group 01 is characterized by a large range of $\delta^{13} \mathrm{C}$ values (from -21.53 to $-14.16 \%$ VPDB), which do not have a strong correlation with $\mathrm{HCO}_{3}$ concentrations, probably due to calcite precipitation in samples that are oversaturated in calcite (ASG-SP-77 and 99) or related to the uptake of atmospheric $\mathrm{CO}_{2}$, that is responsible for decrease in the isotopic ratios in samples ASG-SP-11 and 51 (Fig. 5a). These groundwaters are $\mathrm{Ca}-\mathrm{Mg}-\mathrm{HCO}_{3}$ type.

The gradual increase in alkalinity and $\mathrm{pH}$ corresponds to values of $\delta^{13} \mathrm{C}$ more enriched, characteristic of the Group 02, which have $\delta^{13} \mathrm{C}$ ranging from -15.11 to $-11.68 \%$ VPDB. Group 03 is characterized by more enriched groundwater, with $\delta^{13} \mathrm{C}$ ranging from -8.64 to $-7.11 \%$ VPDB (Fig. 5a). Groundwater from Groups 02 and 03 is mostly $\mathrm{Na}-\mathrm{HCO}_{3}$ type. 

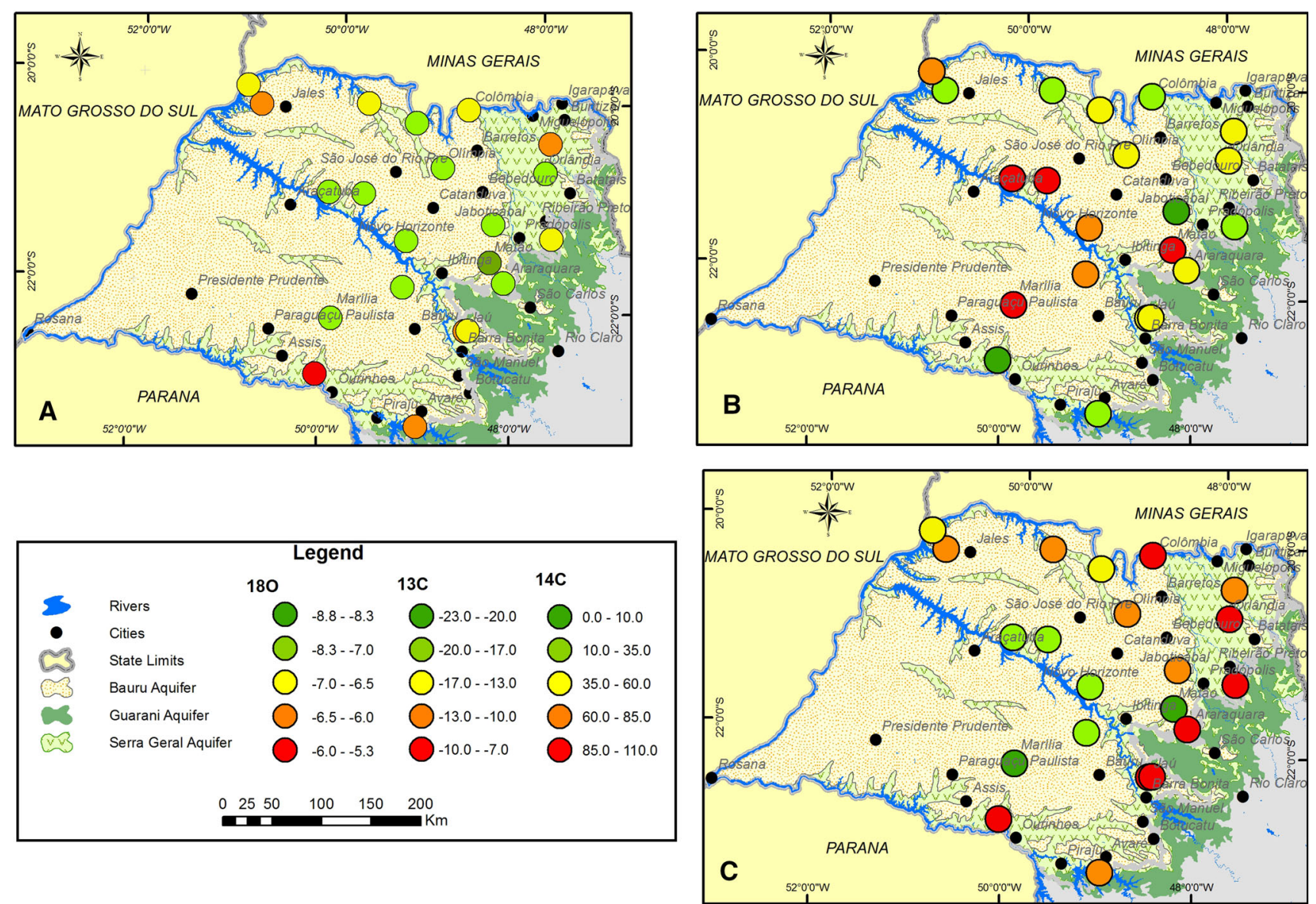

Fig. 4 Spatial distribution along the study area of $\delta 18 \mathrm{O}(\mathbf{a}), \delta{ }^{13} \mathrm{C}(\mathbf{b})$ and ${ }^{14} \mathrm{C}$ activities (c)
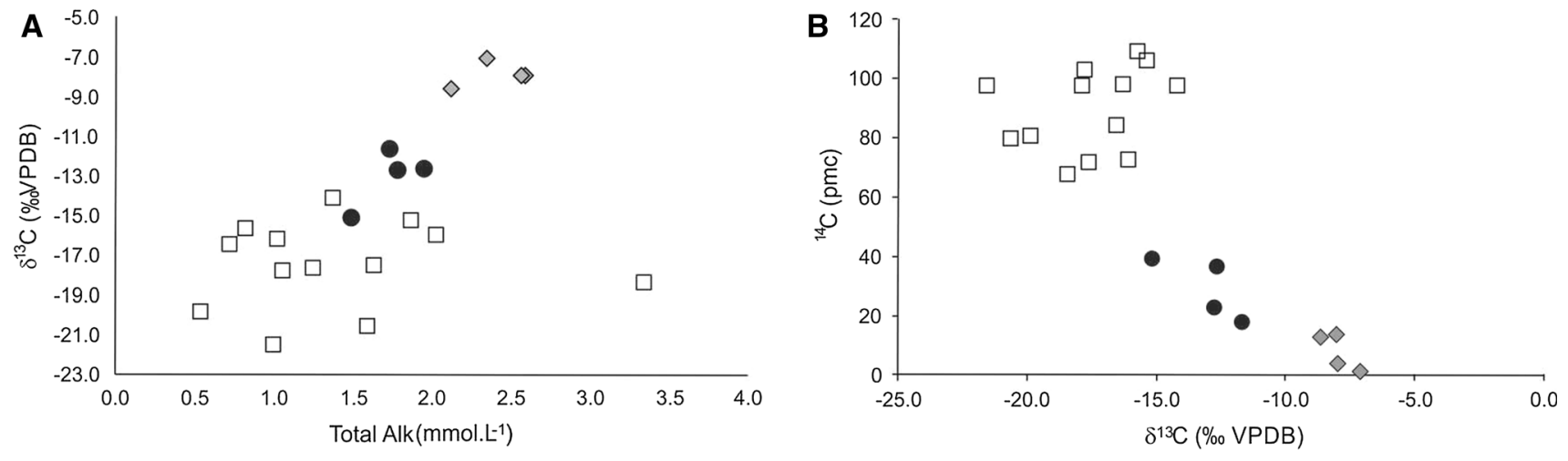

$\square$ Group 01 - Group $02 \diamond$ Group 03

Fig. 5 a $\delta^{13} \mathrm{C}$ versus total alkalinity, showing the increase in alkalinity accompanied for an increase in $\delta^{13} \mathrm{C}$. For samples from Group 01 no correlation is observed between the two variables;

For Group 01, the calculated values for $\delta^{13} \mathrm{C}$ from $\mathrm{CO}_{2}$ present in the soil must be between -29.2 and $-21.85 \%$ VPDB (Table 4), characteristic of plants with a C3 photosynthetic cycle (Clark and Fritz 1997). The calculated value $\delta^{13} \mathrm{C}$ of $\mathrm{CO}_{2}$ for samples from Group 03 is about possible explanation is given in text. b $\delta^{13} \mathrm{C}$ versus ${ }^{14} \mathrm{C}$ activity showing the decrease in activity followed by the decrease in $\delta^{13} \mathrm{C}$

$-15 \%$ VPDB, while samples from Group 02 present intermediate values, about -20\%o VPDB (Table 4).

${ }^{14} \mathrm{C}$ activities measured in SGA groundwater samples range from 108.8 to 1.22 percent modern carbon (pmc), and the relationship between ${ }^{14} \mathrm{C}$ activities and $\delta^{13} \mathrm{C}$ 


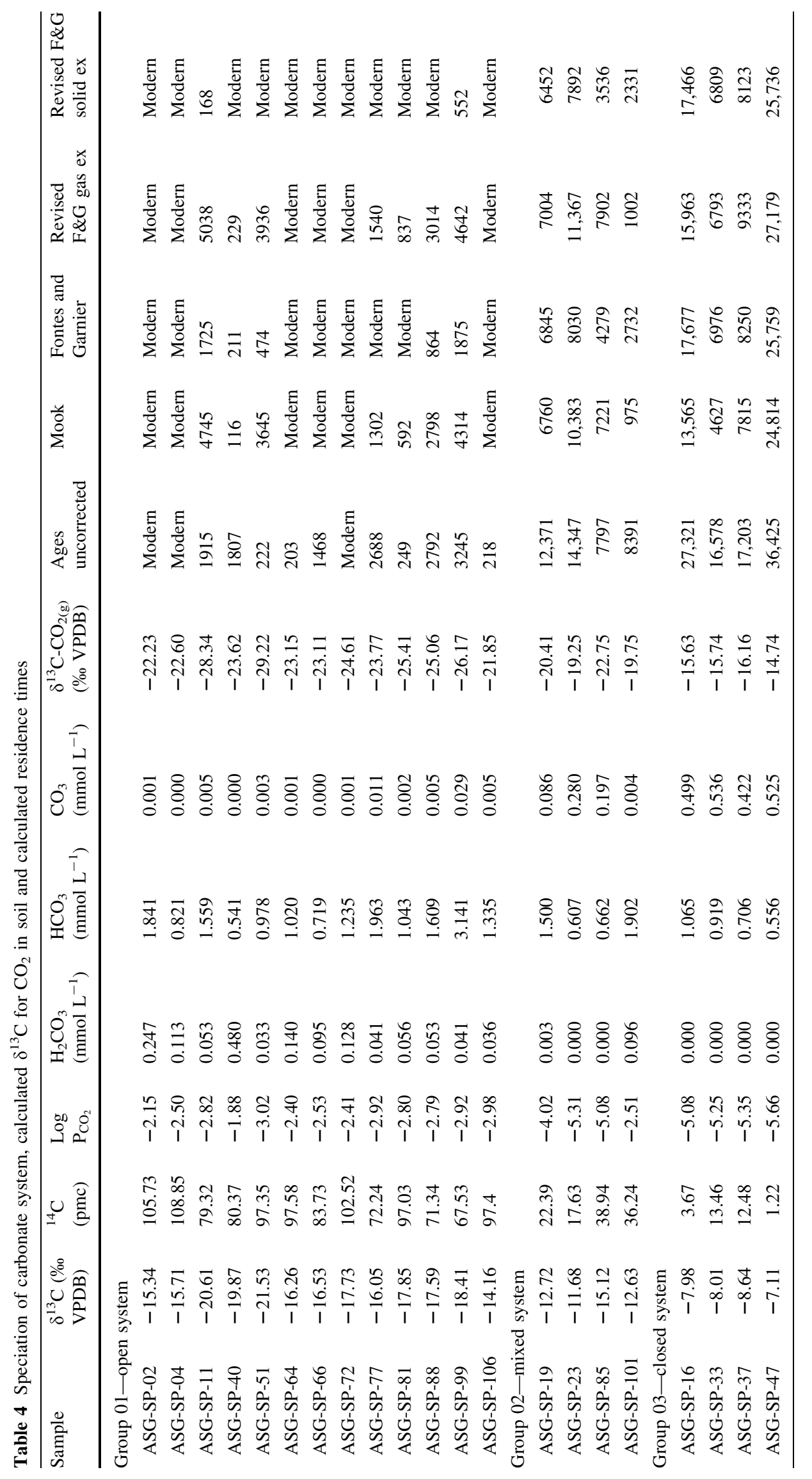


content $(r=-0.81)$ indicates the tendency of decreasing in ${ }^{14} \mathrm{C}$ activity followed by an increase in $\delta^{13} \mathrm{C}$ ratios. The relationship between TDS and ${ }^{14} \mathrm{C}$ activities $(r=-0.77)$ indicates a progressive increase in TDS associated with the decrease in ${ }^{14} \mathrm{C}$ activities, indicating that longer groundwater residence time correlates with greater content of dissolved solids in groundwater. Spatial distribution of ${ }^{14} \mathrm{C}$ activities indicates higher values in outcrop areas, represented by samples from Group 01, decreasing toward the west, where samples from Groups 02 and 03 are present (Fig. 4c).

\section{Discussion}

Groundwater geochemical evolution for samples in Group 01 is mostly related to the incongruent dissolution of plagioclase and pyroxene from basaltic rocks in the presence of atmospheric $\mathrm{CO}_{2}$, leading to secondary formation of kaolinite, releasing major cations (calcium, sodium and magnesium), silica and bicarbonate to solution, according to Eqs. 2 to 4, as previously discussed in Gastmans et al. (2016). As bicarbonate represents the main anion dissolved in SGA groundwater, produced during mineral dissolution reactions by the uptake of atmospheric $\mathrm{CO}_{2}$, a proportional increase in alkalinity with respect to the sum of $\mathrm{Na}, \mathrm{Ca}$ and $\mathrm{Mg}$ concentration is expected, as shown in Fig. 6a, up to the point that groundwater reaches saturation with respect to calcite.

Besides the release of cations and alkalinity, mineral weathering is responsible for the introduction of silica into groundwater.

$$
\begin{aligned}
\underset{\text { anorthite }}{\mathrm{CaAl}_{2} \mathrm{Si}_{2} \mathrm{O}_{8}}+2 \mathrm{CO}_{2}+3 \mathrm{H}_{2} \mathrm{O} \rightarrow & \mathrm{Al}_{2} \mathrm{Si}_{2} \mathrm{O}_{5}(\mathrm{OH})_{4}+\mathrm{Ca}^{2+} \\
& +2 \mathrm{HCO}_{3}^{-}
\end{aligned}
$$

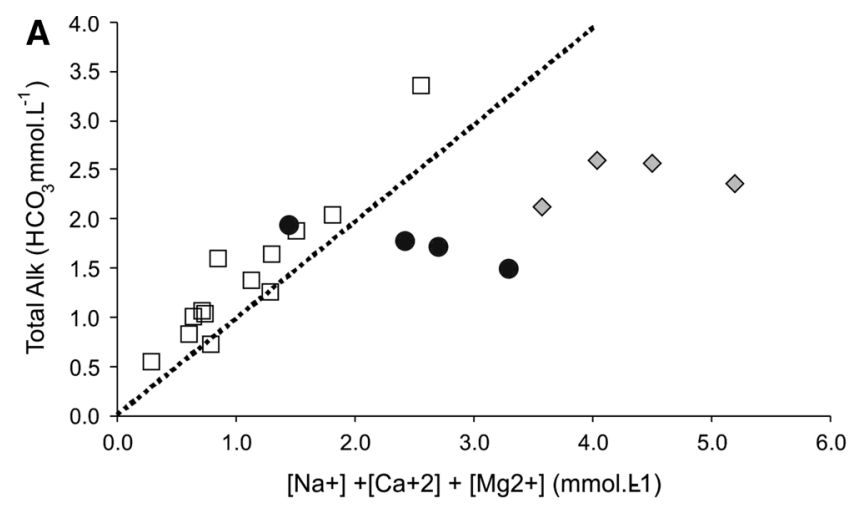

Group 01

Fig. 6 a Relationship between cations (sodium, calcium and magnesium) concentrations and the total alkalinity (expressed as bicarbonate concentration) from SGA groundwater. The dashed line represents the ratio $1: 1$, representing the sum of stoichiometric

$$
\begin{aligned}
& \underset{\text { albite }}{2 \mathrm{NaAlSi}_{3} \mathrm{O}_{8}+2 \mathrm{CO}_{2}+11 \mathrm{H}_{2} \mathrm{O}} \\
& \quad \underset{\text { kaolinite }}{\mathrm{Al}_{2} \mathrm{Si}_{2} \mathrm{O}_{5}(\mathrm{OH})_{4}}+2 \mathrm{Na}^{+}+2 \mathrm{HCO}_{3}^{-}+4 \mathrm{Si}(\mathrm{OH})_{4}
\end{aligned}
$$

(Ca, $\mathrm{Mg}, \mathrm{Fe})_{2} \mathrm{Si}_{2} \mathrm{O}_{6}+2 \mathrm{CO}_{2}+5 \mathrm{H}_{2} \mathrm{O}$

$$
\text { augite }
$$$$
\rightarrow 2\left(\mathrm{Ca}^{+2}, \mathrm{Mg}^{+2}, \mathrm{Fe}^{+2}\right)+2 \mathrm{HCO}_{3}^{-}
$$$$
+2 \mathrm{Si}(\mathrm{OH})_{4}+1 / 2 \mathrm{O}_{2}
$$

Silica concentrations range from 0.36 to $1.15 \mathrm{mmol} \mathrm{L}^{-1}$, presenting a good relationship with $\mathrm{Ca}$ and $\mathrm{Mg}$ concentrations ( $r=0.61$ and $r=0.64$, respectively). All samples are oversaturated with respect to quartz (solubility of $0.18 \mathrm{mmol} \mathrm{L}^{-1} \mathrm{H}_{4} \mathrm{SiO}_{4}$ at $25{ }^{\circ} \mathrm{C}$; Rimstidt 1997) and saturated with respect to chalcedony (solubility of $1.35 \mathrm{mmol} \mathrm{L}{ }^{-1} \mathrm{H}_{4} \mathrm{SiO}_{4}$ at $25{ }^{\circ} \mathrm{C}$; Fournier 1977), but are undersaturated with respect to amorphous silica (solubility of $1.9 \mathrm{mmol} \mathrm{L}^{-1} \mathrm{H}_{4} \mathrm{SiO}_{4}$ at $25^{\circ} \mathrm{C}$; Rimstidt and Barnes 1980) (Table 2). Gastmans et al. (2016) have shown that if the source of silica is directly associated with basaltic mineral dissolution due to uptake of atmospheric $\mathrm{CO}_{2}$, a stoichiometric relationship between concentrations of $\mathrm{SiO}_{2}$ and $\mathrm{HCO}_{3}$, especially for samples in Group 01 should be expected; however, many samples fall below the 1:1 stoichiometric ratio (Fig. 6b). Two geochemical processes in outcrop areas may explain the observed relationship. As groundwater becomes saturated with respect to quartz or chalcedony; removal of $\mathrm{SiO}_{2}$ from the solution by secondary silica precipitation associated with precipitation of silica polymorphs or aluminous silicates (e.g., clay minerals) could be responsible for the decrease in silica concentration compared to alkalinity. The second process could be associated with preferential dissolution of anorthite, causing alkalinity to increase faster than silica content.

For samples in Groups 02 and 03 that have silica values lower than samples from Group 01, the increase in total

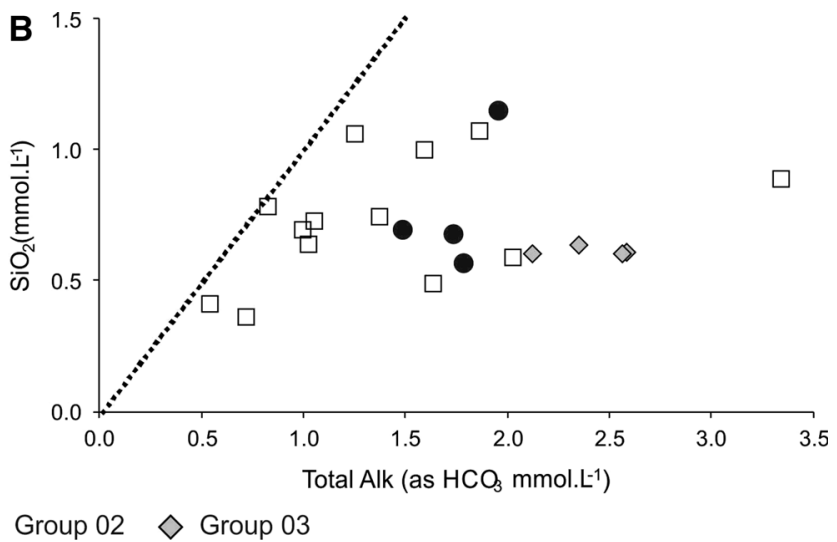

relations observed in Eqs. 2, 3 and 4. b Relationship between silica and total alkalinity (expressed as bicarbonate concentration). The dashed line (1:1) represents the sum of stoichiometric relations observed in Eqs. 2, 3 and 4 
alkalinity is not associated with an increase of silica concentrations. Most samples are saturated or oversaturated with respect to calcite and quartz, but the saturation index of chalcedony and amorphous silica is lower than samples from Group 01. Gastmans et al. (2010a, b) have shown that dissolved silica in the GAS groundwaters shows a tendency to decrease as a function of increasing aquifer confinement, and that the chalcedony saturation index in confined conditions indicates groundwater undersaturated with respect to this silica phase.

Ion exchange processes seem to be the most important factor related to the increase in $\mathrm{Na}$ concentrations for samples from Groups 02 and 03 that is associated with a decrease in $\mathrm{Ca}$ concentrations. It should be observed that this process is not related to reactions presented above (Eqs. 2 to 4 ), so there are two possible explanations. If the increase is related exclusively to groundwater evolution within the basaltic aquifer, calcite precipitation and ion exchange on smectite are possibly an important process controlling $\mathrm{Na} / \mathrm{Ca}$ ratios in the $\mathrm{SGA}$, as observed by Gastmans et al. (2016) in the northern portion of the aquifer, where it is outcropping. On other hand, this cannot explain the observed high values of $\mathrm{pH}$ (up to 9.0) for samples from Groups 02 and 03 . Under closed conditions rapid consumption of $\mathrm{CO}_{2}$ is expected during silicates dissolution; however, there is no important carbon sink in the aquifer framework to explain the observed increase in $\mathrm{pH}$ values.

Higher values of $\delta^{13} \mathrm{C}$ in samples from Groups 02 and 03 is an indication that heavier carbon was introduced to the system. Although measured values for $\delta^{13} \mathrm{C}$ for carbonate minerals filing vesicles in basaltic rocks range from -15 to $-3.72 \%$ VPDB (Kimmelmann et al. 1994), and dissolution of these carbonate minerals can lead to the values measured in dissolved carbon present in groundwater under closed conditions, it should be observed that groundwater is saturated or oversaturated with respect to calcite, as previously discussed, and dissolution of these minerals could not occur.

Several authors have described high $\mathrm{pH}$ alkaline $\mathrm{Na}-$ $\mathrm{HCO}_{3}$ groundwater in the confined zone of GAS associated with ionic exchange (Silva 1983; Meng and Maynard 2001; Sracek and Hirata 2002; Gastmans et al. 2010a, b; Hirata et al. 2011, among others). Geochemical evolution of GAS groundwater along flow paths leads to an increase in $\delta^{13} \mathrm{C}$ values toward the center of the Paraná Basin, reaching values about $-6 \%$ along the Tietê River (Gastmans et al. $2010 \mathrm{a}, \mathrm{b})$, values similar to those observed in groundwater from Groups 02 and 03. The artesian zone of the GAS provides hydraulic evidence of groundwater mixing along the Tietê River (Fig. 1), as previously discussed by Gastmans et al. (2016), using geochemical modeling, along River Grande in the northern portion of the São Paulo
State. Based on these findings, upward groundwater flow from Guarani Aquifer could be responsible for the presence of Na-high $\mathrm{pH}$ and $\delta^{13} \mathrm{C}$-enriched water in SGA.

\section{Groundwater residence time and climatic recharge conditions}

The use of ${ }^{14} \mathrm{C}$ to determine groundwater residence times in aquifers is based on evaluating the radioactive content of dissolved carbonate species in groundwater, which decreases with time since recharge. The method is limited to dating groundwater recharged over the past 30,000-40,000 years, due to the half-life of the isotope (Kulogoski et al. 2008). Other complications for the use of ${ }^{14} \mathrm{C}$ to determine residence time of groundwater are related to the determination of the initial ${ }^{14} \mathrm{C}$ activity $\left(\mathrm{A}_{0}\right)$ and the evolution of $\delta^{13} \mathrm{C}$, which may be influenced by reactions and exchange with external sources of inorganic carbon. Plummer and Glynn (2013) provided an extensive review of radiocarbon dating in groundwater.

${ }^{14} \mathrm{C}$ activities and $\delta{ }^{13} \mathrm{C}$ content are presented in Fig. 5b, showing the tendency of decreasing ${ }^{14} \mathrm{C}$ activity, followed by an increase in $\delta^{13} \mathrm{C}$ ratios. Particularly for Group 01, wide ranges of values for $\delta^{13} \mathrm{C}$ are not directly related to a decrease in the ${ }^{14} \mathrm{C}$ activity, which is consistent with the observed relationship between $\delta^{13} \mathrm{C}$ and total alkalinity.

Due to the introduction of carbon from atmospheric sources and the lack of carbonate minerals in basaltic rocks, calculation of groundwater ages for Group 01 requires only the application of the radioactive decay constant, while for Groups 02 and 03 specific corrections of the initial ${ }^{14} \mathrm{C}$ activity $\left(\mathrm{A}_{0}\right)$ are necessary before the residence time based on radioactive decay is calculated. The residence time of groundwater samples can be determined using the following equation (Clark and Fritz 1997):

$t=-8267 \cdot \ln \left(\frac{A_{0}{ }^{14} C}{A^{14} C}\right)$

where $\mathrm{A}^{14} \mathrm{C}$ refers the measured radiocarbon content in the analyzed sample and $\mathrm{A}_{\mathrm{O}}^{14} \mathrm{C}$ is the radiocarbon activity in the soil $\mathrm{CO}_{2}$ in the recharge areas. Due to the dominance of silicates in basaltic rocks isotopic exchange is not supposed to take part in recharge area, value for $\mathrm{A}_{\mathrm{O}}^{14} \mathrm{C}$ could be assumed to be equal $100 \mathrm{pmc}$, and uncorrected ages were calculated on this basis. However, $\delta^{13} \mathrm{C}$ values were found to vary about $10 \%$ in groundwater from Group 01 to Group 03 , and these variations may reflect different geochemical evolution process, as previously discussed involving silica and total alkalinity variations, as well as the factors related to increase in sodium concentrations. These processes seem to involve mixing of groundwater from GAS, which have very low $14 \mathrm{C}$ activity in the confined zone, with groundwater ages measured using ${ }^{81} \mathrm{Kr}$ reaching almost $1000 \mathrm{ky}$ 
(Aggarwal et al. 2015), and chemical characteristics similar to those observed in SGA groundwater.

According to Plummer and Glynn (2013), several geochemical processes along the flow path can affect the isotopic evolution of groundwater, and the selection of an adjustment model to correct groundwater ages has to take into account these processes. For this work three models, implemented in NETPATH XL codes, were selected to estimate groundwater residence times: (1) Fontes and Garnier (1979), the most geochemical complete of traditional adjustment models, (2) the revised Fontes and Garnier models by Han and Plummer (2013) and (3) the Mook model (Mook 1980), determined to be the most applicable to silicate terrains, because it assumes that cations and alkalinity do not necessarily come from dead carbonate. For both corrections, the calculated value of $\delta^{13} \mathrm{C}_{\mathrm{g}}$ soil was used (Table 4). The value of $\delta^{13} \mathrm{C}$ for the carbonate minerals is assumed to be $-3 \%$ VPDB. The dating of these groundwaters considering natural decay and using both corrections is presented in Table 4.

Groundwater residence times for samples from Group 01 are concordant for all the correction methods selected and indicate that most of the samples have recent ages, reaching a maximum of 3000 years (Table 4). However, groundwater ages corrected based on Mook and revised F\&G models are similar, mainly due to the equilibrium with atmospheric $\mathrm{CO}_{2}$. Higher groundwater residence times are observed in samples presenting lower $\mathrm{P}_{\mathrm{CO}_{2}}$. Due to the absence of isotopic exchange with calcite, groundwater ages calculated according to the revised $F \& G$ solid exchange model tend to be underestimated.

Different geochemical evolution associated with mixing with older groundwaters leads to significant differences in calculated residence times for samples from Groups 02 and 03. As expected, the adjusted ${ }^{14} \mathrm{C}$ residence times were in most of the cases younger than unadjusted ${ }^{14} \mathrm{C}$, due to the reactions that occur during geochemical and isotopic evolution of groundwater. It should be noted that the groundwater ages are in agreement with the proposed division of groups, and greater values are obtained for groundwater from Group 03, up to $10 \mathrm{Ky}$, than 5 to $10 \mathrm{Ky}$ as observed for Group 02.

Urban and agricultural soil processes in the study area can exert pressure on the quality of groundwater, especially on waters that are recently recharged. In the western portion of the state of São Paulo, cases of groundwater contamination by nitrate are reported in several cities (CETESB 2013) related to the management of wastewater and the absence of basic sanitation in these places. Nitrate concentrations above $0.15 \mathrm{mmol} \mathrm{L}^{-1}$ are observed in several groundwater samples, which indicates groundwater contamination, especially in the samples belonging to Group 01 (Fig. 7a). Samples of Groups 02 and 03 seem to be more protected from the leakage of wastewater, probably due to their greater residence times and depth, which provides more protection for this type of contamination. The concentration about $0.1 \mathrm{mmol} \mathrm{\textrm {L } ^ { - 1 }}$ observed for these groups is probably associated with construction aspects of the wells.

Variations in $\delta^{2} \mathrm{H}$ and $\delta^{18} \mathrm{O}$ in groundwater are currently interpreted to be the result of climatic variations occurring during recharge (Clark and Fritz 1997). Groundwater from SGA with low ${ }^{14} \mathrm{C}$ activities has the most negative isotope ratios $\left(\delta^{18} \mathrm{O}<-8 \%\right.$ VSMOW), but mostly shows modern ages with respect to their ${ }^{14} \mathrm{C}$ activities, meaning that the isotopic composition of these groundwater represents the average composition of present day precipitation. It should be noticed that values of d-excess (d-excess $=\delta^{2} \mathrm{H}-$ $8 \delta^{18} \mathrm{O}$, Dansgaard 1964) are very similar for the bulk of samples, and for samples presenting low values for ${ }^{14} \mathrm{C}$ activities $\left({ }^{14} \mathrm{C}<40 \mathrm{pcm}\right)$ values of d-excess are about 10\% VSMOW (Fig. 7b). The most depleted values $\left(\delta^{18} \mathrm{O} \approx-8.0 \%\right.$ VSMOW) are observed to be similar to those recognized in Guarani Aquifer groundwater collected
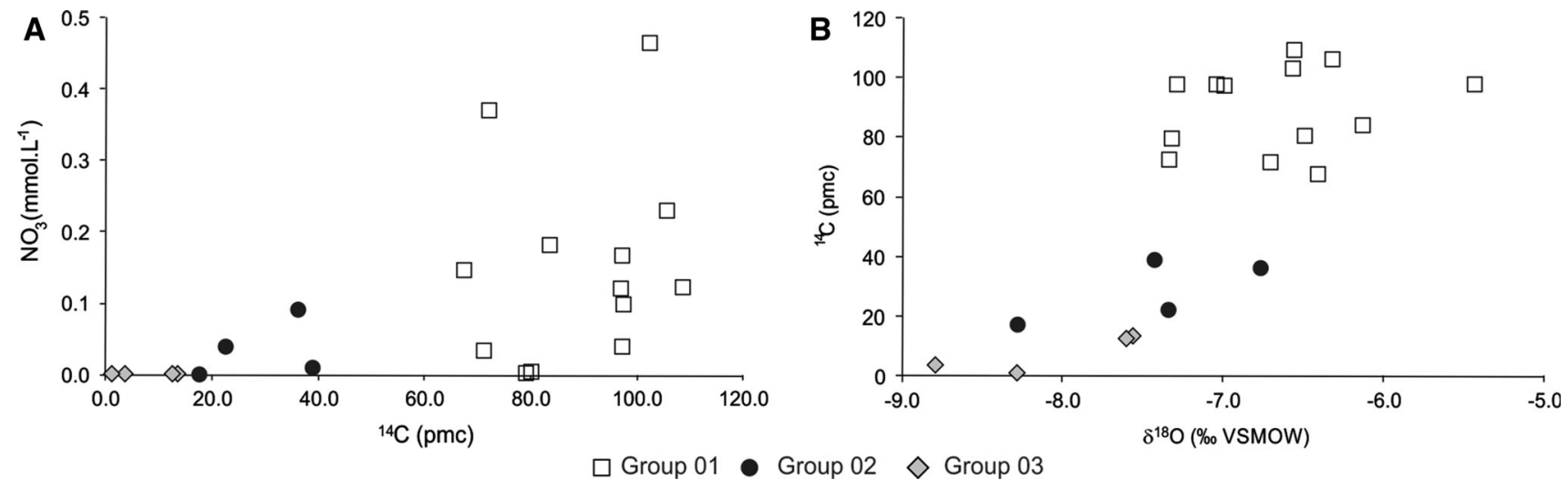

Fig. 7 a ${ }^{14} \mathrm{C}$ activity versus $\mathrm{NO}_{3}$ concentration. Samples from Group 01 present high nitrate concentration. b $\delta^{18} \mathrm{O}$ versus ${ }^{14} \mathrm{C}$ activity, more depleted samples (Groups 02 and 03 ) present low ${ }^{14} \mathrm{C}$ activity 
from wells located in the study area by several authors (e.g., Gallo and Sinelli 1980; Kimmelmann et al. 1986; Chang et al. 2013, among others).

Two processes could be associated with the observed variations observed in isotopic composition. One could be a regional feature, the South Atlantic convergence zone (SACZ), a meteorological system of predominant precipitation zone extending from the Amazon basin in southwest Atlantic Ocean, responsible for more than $75 \%$ of the precipitation over this area. According to Chang et al. (2015) the influence of the SACZ over shallow groundwater leads to more depleted values along this meteorological feature. This corresponds to the northern and central basalt outcrop, while toward the south groundwater is more enriched, reaching $\delta^{18} \mathrm{O}$ isotopic ratios about $-5 \%$ VSMOW. The large variation observed in isotopic composition for modern groundwater also could be associated with the type of rain related to the SACZ. Aggarwal et al. (2016) have found that tropical and midlatitude precipitation can be divided in two types, spatially limited and highintensity convective rains, and frontal and lower-intensity stratiform precipitation. The processes associated with these rain types lead to variations in isotopic composition of precipitation and consequently in groundwater recharge. More depleted precipitation is directly related to stratiform rains, for which values can vary approximately from -30 to $-10 \%$ VSMOW for $\delta^{18} \mathrm{O}$.

\section{Conclusions}

The evaluation of hydrochemical and stable isotopic data from the Serra Geral Aquifer in São Paulo State (Brazil) has contributed to the recognition of the main geochemical processes and controls related to groundwater evolution and groundwater residence times within the basaltic reservoir. Groundwater flow is driven by the topography, and the main rivers crossing the area represent local discharge.

In outcrop areas, groundwater composition is directly related to water-rock interactions, mainly the dissolution of plagioclase and pyroxene, in the presence of atmospheric $\mathrm{CO}_{2}$, leading to an increase in $\mathrm{Ca}-\mathrm{Mg}-\mathrm{HCO}_{3}$ concentrations. The $\delta^{13} \mathrm{C}$ ratios show a large range of values, associated with calcite precipitation and continuous uptake of atmospheric $\mathrm{CO}_{2}$. Variable values for $\delta^{13} \mathrm{C}$ in groundwater samples in outcrop areas lead to different values for $\delta^{13} \mathrm{C}$ of $\mathrm{CO}_{2}$ that are characteristic of plants with a $\mathrm{C} 3$ photosynthetic cycle. This groundwater has been recharged recently, as observed in residence times calculated based on ${ }^{14} \mathrm{C}$ and spatial variations in $\delta^{2} \mathrm{H}$ and $\delta^{18} \mathrm{O}$ composition. The recharge is associated with the most important climatic feature acting over the region, the SACZ, and also with the influence of stratiform fraction of precipitation, which leads to more depleted rain and consequently depleted groundwater recharge.

The wide range of groundwater residence times in the outcrop area indicates a hydrogeological system that is very active, where young waters could be affected by anthropogenic sources of nitrate, while downgradient older groundwater is not affected by nitrate contamination.

When the SGA is under closed conditions, decrease in ${ }^{14} \mathrm{C}$ activities and more depleted values for $\delta^{13} \mathrm{C}$ suggest higher residence times, as do an increase in $\mathrm{pH}$ and $\mathrm{Na}$ concentrations. This is correlated with a gradual increase in the alkalinity that cannot be exclusively explained by dissolution of carbonate minerals present in basaltic rocks. Higher pressure head in wells drilled in the Guarani Aquifer System, which has groundwater with enriched values of $\delta^{13} \mathrm{C}$, and a geochemical evolution, which leads to $\mathrm{Na}-\mathrm{HCO}_{3}$ groundwater types, are factors that can explain the geochemical evolution in the basaltic aquifer under closed conditions and incorporating groundwater mixing between the SGA and GAS.

Acknowledgements This project was funded by a grant from the Fundação de Amparo à Pesquisa do Estado de São Paulo (FAPESP) under the process 2012/00241-5. Authors wish to acknowledge Dr. James W. LaMoreaux, editor in chief of Environmental Earth Sciences, and two anonymous reviewers for suggesting significant improvements to this manuscript.

\section{References}

Abid K, Ammar FH, Weise S, Zouari K, Chkir N, Rozanski K, Osenbrük K (2014) Geochemistry and residence time estimation of groundwater from Miocene-Pliocene and Upper Cretaceous aquifers of southern Tunisia. Quat Int 338:59-70

Aggarwal PK, Gat JR, Froehlich KFO (2005) Isotopes in the water cycle - past present and future of a developing science. Springer, Netherlands

Aggarwal PK, Matsumoto T, Sturchio NC, Chang HK, Gastmans D, Araguás-Araguás LJ, Jiang W, Lu ZT, Mueller P, Yokochi R, Purtschert R, Torgersen T (2015) Continental degassing of $4 \mathrm{He}$ by surficial discharge of deep groundwater. Nat Geosci 8:35-39. doi:10.1038/ngeo2302

Aggarwal PK, Romastschke U, Araguás-Araguás LJ, Belachew D, Longstaffe FJ, Berg P, Schumacher C, Funk A (2016) Proportions of convective and stratiform precipitation revealed in water isotope ratios. Nat Geosci 9:624-629

Alemayehu T, Leis A, Eisenhauer A, Dietzel M (2011) Multi-proxy approach $\left({ }^{2} \mathrm{H} / \mathrm{H},{ }^{18} \mathrm{O} /{ }^{16} \mathrm{O},{ }^{13} \mathrm{C} /{ }^{12} \mathrm{C}\right.$ and $\left.{ }^{87} \mathrm{Sr} /{ }^{86} \mathrm{Sr}\right)$ for the evolution of carbonate-rich groundwater in basalt dominated aquifer of Axun area, northern Ethiopia. Chem Erde-Geochem 71:177-187. doi:10.1016/jchemer.2011.02.007

Bellieni G, Comin-Chiaromonti P, Marques LS, Melfi AJ, Nardy AJ, Papatrechas C, Piccirilo EM, Roisemberg A (1986) Petrogenetic aspects of acid and basaltic lavas from the Paraná Plateau (Brazil): Geological, mineralogical and petrochemical relationships. J Petrol 27:915-944

Bertolo R, Hirata R, Sracek O (2006) Geochemistry and geochemical modeling of unsaturated zone in tropical region in Urânia, São Paulo state, Brazil. J Hydrol 329:49-62 
Betheke CM, Johnson TM (2008) Groundwater age and groundwater age dating. Annu Rev Earth Planet Sci. doi:10.1146/annurev. earth.36.031207.124210

Bittencourt AVL, Rosa Filho EF, Hindi EC, Buchmann Filho AC (2003) A influência dos basaltos e de misturas com águas de aquíferos sotopostos nas águas subterrâneas do Sistema Aquífero Serra Geral na Bacia do Rio Piquiri. Paraná - BR (The influence of the basalts and mixing with water from underlying aquifers in groundwater from Serra Geral Aquifer System - in portuguese). Rev Ag Sub. doi:10.14295/ras.v17i1.1313

Blaser PC, Coetsiers M, Aeschbach-Hertig W, Kipfer R, Van Camp M, Loosli HH, Walraevens K (2010) A new groundwater radiocarbon correction approach for paleoclimate conditions during recharge and hydrochemical evolution: the LedoPaniselian Aquifer, Belgium. Appl Geochem 25:437-455

Boff FE, Medeiros MA, Muller AL, Koppe, JC (2006) Caracterização hidroquímica das águas minerais da Serra do Nordeste Gaúcho (Hydrochemical characterization of mineral water from Serra do Nordeste Gaúcho-in portuguese). In: Proceedings of XIV Brazilian Groundwater Congress, Curitiba (PR)

Bowen GJ (2008) The online isotopes in precipitation calculator, version 2.2. http://www.waterisotopes.org. Cited 10 Apr 2015

Bretzler A, Osenbrück K, Gloaguen R, Ruprecht J, Kebede S, Stadler S (2011) Groundwater origin and flow dynamics in active rift systemd - a multi-isotope approach in the Main Ethiopian Rift. J Hydrol 402:274-289

Campos HCNS (1993) Caracterização e cartografia das províncias hidrogeoquímicas do Estado de São Paulo (Characterization and cartography of hydrogeochemical provinces of São Paulo statein portuguese). Ph.D. thesis, Geosciences Institute-University of São Paulo, São Paulo-SP-Brazil

CETESB (São Paulo) (2013) Qualidade das águas subterrâneas no estado de São Paulo (Quality of groundwater from São Paulo state-in portuguese). http://www.cetesb.sp.gov.br/agua/aguassubterraneas/111-publicacoes-e-relatorios. Cited 04 May 2015

Chang HK, Aravena R, Gastmans D, Hirata R, Manzano M, Vives L, Rodrigues L, Aggarwal P, Araguás-Araguás L (2013) Role of isotopes in the development of a general hydrogeological conceptual model of the Guarani Aquifer (GAS). In: International Atomic Energy Agency. (Org.) (ed) Isotopes in hydrology, marine ecosystems and climate change studies, 1ed, vol 1. Viena, International Atomic Energy Agency, pp 281-290

Chang HK, Dias RG, Stradioto MR, Hespanhol E, Aggarwal PK, Araguás L (2015) Preliminary integrated $\delta^{18} \mathrm{O}$ map of groundwater of three major aquifer systems, south-central region of Brazil. In: Proceedings of international symposium on isotope hydrologyrevisiting foundations and exploring frontiers, Vienna (AU)

Clark ID, Fritz P (1997) Environmental isotopes in hydrogeology. Lewis Publishers, Boca Raton

Clemente CA, Azevedo AC (2007) Mineral weathering in acid saprolites from Subtropical, Southern Brazil. Sci Agric (Piracicaba, Brazil) 64(6):601-607

Coetsiers M, Walraevens K (2009) A new correction model for 14C ages in aquifers with complex geochemistry-application to the Neogene Aquifer, Belgium. Appl Geochem 24:768-776

Cruz FW, Karmann I, Viana O Jr, Burns SJ, Ferrari JA, Vuille M, Sial AN, Moreira MZ (2005) Stable isotope study of cave percolation waters in subtropical Brazil: implications for paleoclimate inferences from speleothems. Chem Geol 220:245-262

DAEE (Departamento de Águas e Energia Elétrica do Estado de São Paulo) (1974) Estudos de Águas Subterrâneas. Região Administrativa 6 - Ribeirão Preto (Groundwater Studies. Administrative Region 6-Ribeirão Preto - in portuguese). São Paulo: DAEE. Vol.2

DAEE (Departamento de Águas e Energia Elétrica do Estado de São Paulo) (1976) Estudos de Água Subterrânea - Regiões Administrativas 7, 8, 9 (Bauru, São José do Rio Preto, Araçatuba)
(Groundwater Studies. Administrative Region 7, 8 and 9 (Bauru, São José do Rio Preto, Araçatuba) - in portuguese). São Paulo: DAEE. Vol.2, 286p

DAEE/UNESP (1980) Mapa Geológico do Estado de São Paulo (Geological Map of São Paulo state) scale 1:250.000

Dafny E, Burg A, Gvirtzman H (2006) Deduction of groundwater flow regime in a basaltic aquifer using geochemical and isotopic data: The Golan Heights, Israel case study. J Hydrol 330:506-524

Dansgaard W (1964) Stable isotopes in precipitation. Tellus $16: 436-468$

Deutsch WJ, Jenne EA, Krupka KM (1982) Solubility equilibria in basalt aquifers: The Columbia Plateau, Eastern Washington, USA. Chem Geol 36:15-34

Domenico PA, Schwartz FW (1998) Physical and chemical hydrogeology. Wiley, Hoboken

Ernesto M, Raposo MIB, Marques LS, Renne PR, Diogo LA, De Min A (1999) Paleomagnetism, geochemistry and 40Ar/39Ar Dating of the Northeastern Paraná Magmatic Province: tectonic implications. J Geodyn 28:321-340

Fernandes AJ, Maldaner CH, Sobrinho JMA, Pressinotti MMN, Wahnfried I (2010) Estratigrafia dos derrames de basaltos da Formação Serra Geral (Ribeirão Preto-SP) baseada na geologia física, petrografia e geoquímica (Stratigraphy of basaltic lava flow from Serra Geral Formation (Ribeirão Preto-SP) based on physical geology, petrography and geochemistry - in portuguese). Ver Inst Geoc - USP 10(2):73-99

Fontes JC, Garnier JM (1979) Determination of the initial ${ }^{14} \mathrm{C}$ activity of the total dissolved carbon: a review of the existing models and a new approach. Water Resour Res 15:399-413

Fournier RO (1977) Chemical geothermometers and mixing models for geothermal systems. Geothermics 5(1-4):41-50

Gallo G, Sinelli O (1980) Estudo hidroquímico e isotópico das águas subterrâneas na região de Ribeirão Preto (SP) (. Rev Bras Geociênc 10:129

Gastmans D, Chang H.K. (2012) Circulação das Águas Subterrâneas do Sistema Aquífero Guarani nas Proximidades da Zona de Afloramentos no Estado de São Paulo (Guarani Aquifer System groundwater circulation pattern in the vicinity of outcrop zone in São Paulo state-in portuguese). In: Proceedings of XVII Brazilian Groundwater Congress Bonito(MS)

Gastmans D, Chang HK, Hutcheon I (2010a) Groundwater geochemical evolution in the northern portion of the Guarani Aquifer (Brazil) and its relationship to diagenetic features. Appl Geochem. doi:10.1016/j.apgeochem.2009.09.024

Gastmans D, Chang HK, Hutcheon I (2010b) Stable isotopes $\left(\delta^{2} \mathrm{H}\right.$, $\delta^{18} \mathrm{O}$ and $\left.\delta^{13} \mathrm{C}\right)$ in groundwaters from the northwestern portion of the Guarani Aquifer System (Brazil). Hydrogeol J. doi:10. 1007/s10040-010-0612-2

Gastmans D, Hutcheon I, Menegário AA, Chang HK (2016) Geochemical evolution of groundwater in a basaltic aquifer based on chemical and stable isotopic data: case study from the Northeastern portion of Serra Geral Aquifer, São Paulo state (Brazil). J Hydrol 535:598-611. doi:10.1016/j.jhydrol.2016.02.016

Glynn PD, Plummer LN (2005) Geochemistry and understanding of groundwater systems. Hydrogeol J 13:263-287

Han LF, Plummer LN (2013) Revision of Fontes \& Garnier's model for the initial $14 \mathrm{C}$ content of dissolved inorganic carbon used in groundwater dating. Chem Geol 351:105-114. doi:10.1016/j. chemgeo.2013.05.011

Hirata R, Gesicki A, Sracek O, Bertolo R, Giannini PC, Aravena A (2011) Relation between sedimentary framework and hydrogeology in the Guarani Aquifer System in São Paulo state, Brazil. J South Am Earth Sci 31(4):444-456

IAEA/WMO (2006) Global network of isotopes in precipitation: the GNIP database. IAEA/WMO, Vienna. http://isohis.iaea.org. Cited Apr 222013 
Kimmelmann e Silva AA, Silva, RBG, Rebouças AC, Santiago MMF. (1986) Hidrologia Isotópica do Aquíffero Botucatu - Bacia do Paraná - Brasil (Isotopic hydrology of Botucatu Aquifer-Paraná Basin-Brazil-in portuguese). In: Proceedings of IV Brazilian Groundwater Congress, Brasília (DF)

Kimmelmann e Silva AA, Foster M, Coelho R (1994) Environmental isotope and hydrogeochemical investigation os Bauru and Botucatu aquifers, Paraná Basin, Brazil. Estudios de hidrogeologia isotópica en América Latina, IAEA, Vienna, Tec. Doc. 835

Kulogoski JT, Hilton DR, Cresswell RG, Hostetler S, Jacobson G (2008) Helium-4 characteristics of groundwater from Central Australia: comparative chronology with chlorine-36 and carbon14 dating techniques. J Hydrol 348:176-194

Lastoria G, Sinelli O, Chang HK, Hutcheon I, Paranhos Filho AC, Gastmans D (2006) Hidrogeologia da Formação Serra Geral no Estado de Mato Grosso do Sul (Serra Geral formation hydrogeology in Mato Grosso do Sul state-in portuguese). Rev Ag Sub. doi:10.14295/ras.v20i1.9727

Léonardi V, Arthaud F, Grillot JC, Avetissian V, Bochnaghian P (1996) Modélisation d'un aquifère basaltique fracturé tenant comptes de données géologiques, climatiques et hydrauliques: cas de Basaltes Perchés de Garni (Arménie) (Modelling of fractured basaltic aquifer based on geological, climatic and hydraulic data: case of. Basaltes Perchés de Garni (Arménie)—in french. J Hydrol 179:87-109

Locsey KL, Cox ME (2003) Statistical and hydrochemical methods to compare basalt and basement rock hosted groundwaters: atherton Tablelands, Northeastern Australia. Environ Geol 43:698-713

Machado FB, Nardy AJR, Oliveira MAF (2007) Geologia e aspectos petrológicos das rochas intrusivas e efusivas Mesozóicas de parte da borda Leste da Bacia do Paraná no Estado de São Paulo (Geology and petrological aspects of Mesozoic intrusive and efusefe rocks in a portion of the East bord of Paraná Basin in São Paulo state - in portuguese). Rev Bras Geoc 37(1):64-80

Milani EJ, França AB, Schneider RL (1994) Bacia do Paraná (Paraná Sedimentary Basin-in portuguese). Bol Geoc Petrol 8(1):69-82

Mook WG (1980) The dissolution-exchange model for dating groundwater with ${ }^{14} \mathrm{C}$. In: Fritz P, Fontes JC (eds) Handbook of environmental isotopes geochemistry, vol 1. Elsevier, Amsterdam, pp 55-74

Nardy AJR, Oliveira MAF, Betancourt RHS, Verdugo DRH, Machado FB (2002) Geologia e Estratigrafia da Formação Serra Geral (Geology and stratigraphy of Serra Geral formation-in portuguese). Rev Geoc 21(2):15-32

OAS (Organization of American States) (2009) Aquífero Guarani: programa estratégico de ação - Acuífero Guarani: programa estratégico de acción - Edição bilíngue - Brasil; Argentina; Paraguai, Uruguai (Guarani Aquifer - Strategic Actions Program - Bilingual edition, in portuguese and spanish), p 424

Parkhurst DL, Appelo P (1999) User's guide to PHREEQC (version 2)-A computer program for speciation, speciation, batchreaction, one-dimensional transport and inverse geochemical calculations: U.S. Geological Survey Water-Resources Investigations Report 99-4259, Denver

Parkhurst DL, Charlton SR (2008) NetpathXL—an Excel ${ }^{\circledR}$ Interface to the program NETPATH. U.S. In: Geological survey techniques and methods 6-A26, p 11

Pearson FJ (1965) Use of C-13/C-12 ratios to correct radiocarbon ages of material initially diluted by limestone. In: Proceedings 6th international conference on radiocarbon and tritium dating, Pullman, Washington, pp 357-366

Plummer LN, Glynn PD (2013) Radiocarbon dating in groundwater systems. In: IAEA (ed) Isotope methods for dating old groundwater. pp 35-89
Plummer LN, Busby JF, Lee RW, Hanshaw BB (1990) Geochemical modeling of the Madison Aquifer in parts of Montana, Wyoming and South Dakota. Water Resour Res 26(9):1981-2014

Plummer LN, Prestemon EC, Parkhurst DL (1994) An interactive code (NETPATH) for modeling NET geochemical reactions along a flow PATH, version 2.0: U.S. In: Geological survey water-resources investigations report 94-4169, p 130

Rebouças AC, Fraga CG (1988) Hidrogeologia das rochas vulcânicas do Brasil (Hydrogeology of vulcanic rocks in Brazil-in portuguese). Rev Bras Águas Sub 12:29-55

Renne PR, Ernesto M, Pacca IG, Coe RS, Glen JM, Prévot M, Perrin M (1992) The age of Paraná flood volcanism, rifting of Gondwanaland, and the Jurassic-Cretaceous boundary. Science 258:975-979

Renne PR, Deckart K, Ernesto M, Féraud G, Piccirillo EM (1996) Age of the Ponta Grossa dike swarm (Brazil), and implications to Paraná flood volcanism. Earth Planet Sci Lett 144:199-211

Rimstidt JD (1997) Quartz solubility at low temperatures. Geochim Cosmochim Ac 61:2553-2558

Rimstidt JD, Barnes HL (1977) The kinetics of silica-water reactions. Geothermics 5(1-4):41-50

Rimstidt JD, Barnes HL (1980) The kinetics of silica-water reactions. Geochim Cosmochim Acta 44:1683-1699

Rosanski K, Araguás-Araguás L (1995) Spatial and temporal variability of stable isotope composition of precipitation over the South American continent. Bull Inst Franc Études Andines 24(3):379-390

Rosenthal E, Jones BF, Weinberger G (1998) The chemical evolution of Kurnub Group paleowater in Sinai-Negev province-a mass balance approach. Appl Geochem 13(5):553-569

Scheiber L, Ayora C, Vázquez-Suñé E, Cendrón DI, Soler A, Custodio E, Baquero JC (2015) Recent and old groundwater in the Nieba-Posadas regional aquifer (southern Spain): implications for its management. J Hydrol 523:624-635

Scherer CMS (2000) Eolian dunes of Botucatu formation (Cretaceous) in Southernmost Brazil: morphology and origin. Sediment Geol 137:63-84

Silva RBG (1983) Estudo Hidroquímico e isotópico do Aquífero Botucatu no Estado de São Paulo (Hydrochemical and isotopic study of Botucatu aquifer in São Paulo state, in portuguese) PHD Thesis. Geosciences Institute-University of São Paulo, São Paulo-SP-Brazil

Sracek O, Hirata R (2002) Geochemical and stable isotopic evolution of the Guarani Aquifer in the State of São Paulo, Brazil. Hydrogeol J 10:643-655

Tamers MA (1975) Validity of radiocarbon dates on groundwater. Geophys Surv 2:217-239

Vuille M, Werner M (2005) Stable isotopes in precipitation recording South American summer monsoon and ENSO variability: observations and model results. Clim Dyn 25:401-413

Vuille M, Bradley RS, Werner M, Healy R, Keimig F (2003) Modeling $\delta^{18} \mathrm{O}$ in precipitation over the tropical Americas: 1. Interannual variability and climatic controls. J Geophys Res. doi:10.1029/2001JD002038

Wahnfried I (2010). Modelo Conceitual de Fluxo do Aquitarde Serra Geral e do Sistema Aquífero Guarani na Região de Ribeirão Preto (SP) (Serra Geral aquitard and Guarani Aquifer System concetual flow model in the region of Ribeirão Preto (SP) - in portuguese). Ph.D. thesis Geosciences Institute-University of São Paulo, São Paulo-SP-Brazil

Zalán PV, Wolf S, Conceição JCJ, Marques A, Astolfi MAM, Vieira IS, Appi VT, Zanotto AO (1986) Bacia do Paraná (Paraná Basin-in portuguese). In: Rajagabaglia GP and Milani EJ Origem e Evolução de Bacias Sedimentares (Origin and evolution of Sedimentary Basins) Bol Téc Petrobras 